\begin{tabular}{|l||c|c||}
\hline \hline Received 03.12.2021 & JOTS \\
\hline \hline Accepted 16.12.2021 & Research Article & $6 / 1$ \\
\hline \hline Published 01.01.2022 & & $2022: 54-84$ \\
\hline
\end{tabular}

\title{
Tantrik Türk Budizmi'nde Cinsel Kucaklaşma Sembolü Yab Yum Üzerine
}

\author{
On the Symbol of Sexual Embrace Yab Yum in Tantric Turkish Buddhism
}

\author{
Hasan İ İ \\ ( Ankara/Turkey) \\ E-mail: hasanisi21@yahoo.com.tr
}

\begin{abstract}
As a school of Mahāyāna Buddhism, Tibetan Buddhism, which emerged from Tibet in the VIIth century AD and spread to neighboring and distant geographies from Tibet, is a branch of Buddhism that aims to enlightenment through meditation and magic. It is also known as Tibetan Buddhism, Tantric Buddhism or Esoteric Buddhism, which aims to purify the person through various methods in the state of meditation with teaching techniques such as mantra, dhāraṇi, mandala and mudrā. Tibetan Buddhism, which steered the tradition of XIVth century Central Asian Buddhism, visualized various rituals with both various depictions and painting and sculpture art, and especially reflected this sexual symbolism such as sexual intercourse and sexual embrace in the personality of female gods, female Buddhas, female Bodhisattvas and protective Deities (yidams). The Sexual Embrace, a product of Tantric Sex symbolism, is described by the Tibetan term yab yum. This term describes the embrace of Buddha-Mother and BuddhaFather as the primordial union of wisdom and compassion. Sexual Embrace, which is also seen in Buddhist Uyghurs, is understood by the use of the words ög qay, ög t(ä)yri qızı, quč- and qučmaq in the descriptions in the texts of Berliner Turfantexte VII and Berliner Turfantexte XXXVI. Accordingly, in the first part of this study, which consists of two parts, the religious value of the Tibetan yab yum expression is shown in detail by including the opinions of various researchers, the appearance of the Tibetan yab yum form in Buddhist Uyghurs, which is theoretically informed, is discussed in the second part and responds to this sexual symbolism. The narrations are tried to be shown iconographically with pictures.
\end{abstract}

Key Words: Uyghur Tantrism, Tantric Turkish Buddhism, Sexual Embrace, yab yum.

ORCID ID: 0000-0001-7269-3596. 


\section{ग(ब)}

\section{Giriş}

XIV. yüzyıl Moğol-Yuan Hanedanlığı içerisindeki siyasî ve dinî gelişmelere bağlı olarak Budist Uygurlarca bir zorunlu tercih olarak benimsenen Tibet Budizmi, hem dharma felsefesine dair güncel bilgiler hem de bünyesinde çeşitli öğreti teknikleri barındırması bakımından Klasik ve Mahāyāna Budizmi'nin aksine, canl, hareketli ve cinsellik gibi yaşamın gerçeklerini sistematik bir şekilde Budizm ile bütünleştiren bir akımdır. Budist Uygurlarca ilk ürünleri, XIV. yüzyılın ilk yarısına tarihlenen öğreti kitapları ile verilen Tantrik Türk Budizmi, Uygur Tantrizmi ya da Tantrik Uygur Budizmi gibi adlandırmalara da sahiptir. Budist Uygurlarda Tantrik geleneğin yansımalarını, ritüellerde birbirini tamamlayan büyülü sözler olarak bilinen dhāraṇi ve mantralar, ritmik dinî el-kol hareketleri (mudrālar), meditasyon eşliğinde kutsal daireler (maṇdalalar) gibi öğreti teknikleri ile Tibet yerel inancının etkisini gösteren doğal afetlerden, şeytanlardan, kötü ruhlardan, kötü doğumlardan, kötü gezegen etkilerinden korunmayı amaçlayan anlatılar içerisinde görmekteyiz. Çeşitli vaatlerin Tantrik ustalarca verildiği Budist Uygur metinlerinde, özellikle ritüellerde ön plana çıkan Guru, dişi tanrılar ve Budalar, Bodisattvalar, Koruyucu tanrılar (yidamlar) gibi şahsiyetler yanında aydınlanmayı beden fizyolojisi içerisinde ve çeşitli nesnelerle cinsel semboller kullanarak aktarma durumu da söz konusudur. $\mathrm{Bu}$ cinsel sembolizm unsurlarından biri de, Tibetçede yab yum 'ebeveyn; anne-baba' olarak bilinen ve Tantrik sembolizm içerisinde aydınlanmaya cinsel ilişki yoluyla ulaşmayı amaçlayan Cinsel Kucaklaşma ve Tam Benimseme terimleri, Budist Uygur metinlerinde de görülmektedir. Bu kavrama dair anlatılar, Budist Uygur metinlerinde ög kay, ög t(e)yri kızı, kuç- ve kuçmak sözcüklerinin birlikte kullanıldığı Tantrik metinlerden Berliner Turfantexte VII ve Berliner Turfantexte XXXVI içerisinde tanıklanmaktadır.

$\mathrm{Bu}$ yönüyle, eldeki çalışma iki bölümden oluşmaktadır. Çalışmanın ilk bölümünde, cinsel bir sembolizm örneği olarak Tibetçe yab yum terimine değinilerek kavramın Budist düşünce sistemi içerisinde sahip olduğu görünüm ortaya konmuş ve devamında bu kavramın Tantrik Türk Budizmi'ndeki tanıklarından hareketle, yab yum 'cinsel kucaklaşma' formuna dair anlatılar, Berliner Turfantexte VII ve Berliner Turfantexte XXXVI'daki tasvirlerle ikonografik olarak okuyuculara sunulmuş ve terimin sahip olduğu kavramsal değer gösterilmeye çalışılmıştır. 


\section{Tibet Budizmi'nde Cinsellik ve Yab yum}

Tibetçede yab yum 'ebeveyn; anne-baba' anlamında özellikle Tibet Budizmi'ne dayalı düşünce sistemlerinde, meditasyon durumlarında Buda annesi ve Buda babasının cinsel kucaklaşmasını anlatan sembolik bir terimdir. Cinsel kucaklaşma, cinsel birleşme ve tam benimseme gibi kavramlarla da anlatılan Tibetçe yab yum kavramı, bir kucaklaşma sembolü olarak Budist Tantrik inançta, aydınlanmayı kadın ve erkeğin birlikteliği içerisinde arama amacının ürünüdür. Budist gelenekte, yab yum sembolizmine dair bilgiler, hem Tantralardaki anlatılarda hem de heykel ve resimlerde birbirini kucaklayan kadın-erkek figürlerinde görülmektedir. Bu sebeple, eldeki çalışmanın bu bölümü, Tibetçe yab yum sembolizmini açıklamak amaçlı çeşitli başlıklardan oluşur. Bu başlık içerisinde, Budizm'de cinsellik, klasik ve Mahāyāna Budizmi'nde kadına bakış, Tibet Budizmi'nde cinsellik ve cinsellik sembolleri gibi bölümler, Tibet Budizmi'ne dayalı Budist Uygur metinlerinde etkisi görülen yab yum sembolizminin kökenlerini, sahip olduğu değeri ve sembolik içeriği göstermesi bakımından önemlidir.

\subsection{Budizm'de Cinsellik}

Sanskritçede kama 'aşk' veya 'arzu' anlamında, özellikle cinsel arzuyu tanımlayan bir terimdir. Sözcük, üç âlemin (dhātu) hiyerarşik düzeninde, arzu âlemi (kāmadhātu) olarak bilinen en aşağı seviyeyi anlatır (Keown, 2003: 135). Türkçe Sözlük'te 'Cinsel özelliklerin bütünü, eşeysellik ya da sevişme duygusu, seksüellik' anlamlarına gelen cinsellik, Budist düşünce sisteminde özellikle Tibet Budizmi öncesi, Klasik ve Mahāyāna Budizmi'nde manastır üyelerinin dikkatini dağıtmamak için yasaklanan, manastır üyesinin kovulması ve gruptan dışlanması gibi sonuçlara yol açabilecek bir eylemdir. Budizm'in cinselliğe olan bakışı, genellikle bir erkek için kadın varlığının ifade ettiği çekicilik, baştan çıkarıcllk, ayartma, şehvet gibi kavramlarla açıklanmakta ve kadın figürü, Budistler açısından olumsuz bir varlık olarak görülmektedir.

Budizm'e göre, bireyin doğum gibi bir süreçten geçmesiyle dünyaya gelmesinin cinsel ilişki ile bir ilgisi yoktur. Cinsellik, saf dünya içerisinde yaşayan varlıkların açgözlülüğü sonucu beliren bir kavramdır. Budistler, bu kavramlarla alakalı bilgileri inanırlarına şu şekilde hikâye etmektedir:

Doğum ve ölüm döngüsünün başlangıcı yoktur. Çeşitli dünyalar Tanrı tarafından değil, canlı varlıkların karması tarafından yaratılır ve yok edilir. Ilk olarak, fiziksel bir dünya 
oluşur, ardından buraların içi doldurulmaya başlanır. Doğan ilk varlıkların yiyeceğe ve içeceğe aynı zamanda da bir cinsiyet sınıfına girmeye ihtiyacı yoktur. Yaşadıkları yerin yüzeyi köpüklü bir madde ile kaplıdır. Canlılardan biri bunu tadar. Diğerleri onu tüketmeye başlar ve bu tüketim vücutlarının ağırlık ve yoğunluk kazanmasına neden olur. Uçamazlar ve vücutları parlaklığını kaybeder. Onlar, doğal olarak kendiliğinden pirince dönüşen köpüklü maddeyi fazlaca tükettikleri için, vücutlarındakileri dışarı atmaları gerekir, bu da (anüs, genital bölgeler) alt deliklerin gelişmesine neden olur; böylece iki cinsiyet belirir: kadın ve erkek. Kısa sürede, bir erkek ve bir dişi çiftleşmeyi keşfeder. Dünyanın diğer varlıkları, çiftleşmelerinden o kadar iğrenirler ki, onları toprak bile üstünden atmaya başlarlar. Bu çift, kendilerini başkalarının saklamak için ilk sığınağı inşa eder. Cinsiyet, cinsellik, barınma, özel mülkiyet, toplum, şehvetli ve zevki arayan varlıkların merakının ve nihai açgözlülüğünün sonuçlarıdır (Gendun Chopel, 2018:120).

Budist doktrine göre anlatılan bu hikâyede, cinsel birliktelik var olan birçok iyi yaşama gölge düşüren, varoluştaki tüm saflı̆̆ı, iğrençliğe döndüren, temeli şehvet ve arzulara göre şekillenen bozulmaların sebebidir. Bu bozulmalar, insan varlığının yenilmemesi gereken bir şeyi tatması, ona karşı bir bağımlılık ve tutku yaşayıp devamında yenilen şeylerin dışa salınımı sonucunda beliren genital bölge kavramı ile şehvet ve arzu duygularına yönelmesinden ileri gelmektedir. Ayrıca, bu tercih sayesinde var olan birçok kavram (toplum, mülkiyet, barınma vb.) ortaya çıkıp sahip olunan birçok iyi yaşam formları yitip gitmiştir. Tanrı tarafından bahşedilmeyen bu cinsellik, tüm kötü karmaların da temel sebebidir.

Cinsellik, Buda'nın kurduğu erkek çileciler topluluğunun bağlarını bozmaktadır. Cinsellik, genellikle birlikte yaşayan, çocuk yetiştiren ve aile oluşturan çiftler arasında duygusal bağlara yol açan bir eylem olarak bilinse de Saṃgha, bir kişinin yoldaşlarının desteğiyle güçlenen bir özgürleşme yolunu izleyen, ortak dinî idealler peşinde koşan, üyeleriyle işbirliği yapan bir toplum olarak gruba bağlılığı ön plana alan bir sisteme sahiptir. Buda, zevkten soyutlanmayı ve iyi karmayı hedefleyen bir dharma sistemi geliştirmiş ve bu mükemmellik herkes tarafından anlaşılmıştır (Powers, 2009: 100, 111).

Zamanla gelişen eşyaya, varlığa ve tensel doyuma dayalı dünya yaşamı Budist düşünürlerce şehvet duygusunun insanda güçlü olduğu sonucuna varmalarını sağlamıştır. Budistlerce, cinsellik, genellikle kurtuluşun önündeki birincil engel olarak görülse de, bazı Budistler cinselliğin doğru kullanıldığında arzu ve zevkin uygulayıcılar için aydınlanmaya giden bir yol sunabileceğini iddia ettiler. Ancak, çoğu zaman karşı çıkılan ve Budist topluluğu bozacağına inanılan 
cinsel ilişki, yine de her zaman Budist yolda ilerlemenin önünde ciddi bir engel olarak kabul edildi:

Vinayalarda, ister insanlarla, ister ilahi varlıklarla veya hayvanlarla olsun, genital, oral veya anal seksin kesinlikle yasak olduğu açıkça belirtilir. Erkeklerin cinsel doyuma yönelik şehvetinin suçu, kadınlara yüklenir. Bunun arkasında, ortodoks veya ana akım Budizmi'ndeki, uyanma hedefine ulaşmak için cinsel arzunun bastırılması gerektiği konusundaki ısrar gelmektedir. Onlara göre, vücut daima, kan ve irin, idrar ve dışkı ile dolu bir deri torbası olmalıdır (Buswell, 2004: 761, 762).

Görüldüğü üzere, ilgili pasaj, Saṃgha'nın tüm üyeleri için özellikle erkekler için bekârlığın zorunlu olmasını göstermektedir. Vücudun şehvet ve arzu dürtüleri neticesinde salgıladığı mutluluk sıvılarını reddeden bu görüş, vücudu daima kan, irin vb. sıvılarla dolu bir torba olarak düşünüp cinsellik noktasında erkeklerin kadınların cazibesine kapılma tehdidini vurgulamaktadır. Bu tehdit, Buswell tarafından şu şekilde de dile getirilmiştir:

Kadınların bekârlığa karşı oluşturduğu tehdit, erkek yazarlı Budist metinlerde genellikle kadınların, cinsellik ve şehvetle ilişkilendirilen ahlaksız ve baştan çıkarıcılar olarak görülmesini sağlamıștır. Kadınlar, tamamen Māra'nın tuzakları olarak tanımlanıp kontrol edilemeyen şehvetleri tarafından yönlendirilen, doyuma asla ulaşmayan varlıklar olarak anlatılmıştır. Kadın vücudunun saf olmadığı ve âdet görme gibi kadın biyolojik süreçleri, pis ve kirletici olarak da görülmektedir (Buswell, 2004: 303).

Buswell tarafından dile getirilen bu görüşe bakıldığında, kadına olan bakış, Buda'nın aydınlanmaya çalışırken onu tehdit etmeye çalışan, bunu başaramayınca Buda'ya kızlarını yollayan Māra'yı hatırlatmaktadır. Bu anlatı temelinde, kadınlar bir Māra olarak görülmüş, özlerinde var olan şehveti yönetemeyip birçok erkeği şehvetle yoldan çıkarmasıyla bilinmiştir. Kadına dayalı bu anlatılar, sadece haz duygusu ile sınırlı kalmamış, kadınların âdet görmeleri bile, kadın saflığını ortadan bir durum olarak görülmüş̧ür. Bu da özü kadın, sonu cinsel birleşme olan seks kavramının Budistlerce, hoş görülmediğini, bir tabu olarak manastır üyelerine yasaklanmasını sağlamıştır.

Budizm'in cinselliğe dair bakışını kadın figürü temelinde yansıtan bu görüşler dışında, cinselliğe dair asıl çekince, cinsel birleşme eyleminin dharma'y1 gerçekleştirme noktasında sorunlara yol açması fikrinden ileri gelmektedir. Keown, dharma felsefesine ters düşen bu durumu şu şekilde ifade etmektedir:

Budizm'de seks, dünyevî yaşamla güçlü bir bağ olarak kabul edilir ve evinden ve ailesinden vazgeçmiş bir manastır üyesi için bu faaliyet uygun değildir. Budizm, özlemi (tṛ̦ṇā) 1stırabın (duhkhha) nedeni olarak gördüğünden, cinsel arzunun tehlikeleri açıktır ve Budist 
literatürde buna sıklıkla işaret edilir. Vinaya veya manastır kanununda bekâr kalmayan keşişler ve rahibeler için katı cezalar vardır. Dört pārājika'nın ${ }^{1}$ ilki, cinsel ilişkiyi yasaklar ve bunu bozmanın cezası ömür boyu cemaatten atılmadır. Vinayalarda bildirilen mastürbasyon veya açı saçık davranışlar gibi küçük suçlar, daha az cezalandırılır (2003: $51)$.

Dünyevî arzuların ve ihtirasların güçlü temsilcisi olarak görünen cinsellik, Budist felsefe sisteminde, 1stırapların kaynağı olarak acı kavramına işaret etmektedir. Dharma yolunda olan bir Budist inanırın uzak durması zorunluluk olan cinsellik kavramı, dharma gerçeği temelinde özellikle manastır sistemi içerisinde rahip ve rahibeler açısından birçok cezayı beraberinde getirmektedirler. Çünkü manastır üyelerinin sahip olduğu nitelik, Budist topluma rol-model olmalarından ileri gelmektedir. Budist düşünce sisteminin halka anlatılmasında aracı rol oynayan rahip ve rahibelerin kutsal görülen dharma inancını bir kenara birakıp kendilerini fiziksel ve ruhsal doyumlarda bulması, dharma'nın başarısını, kalıcılı̆̆ını ve saflığını gölgeleyen bir durum olarak görülmektedir. Bu duruma dair, Budist manastır sistemi içerisinde alınan önemler, Powers tarafından bir vaat/ideal olarak şu şekilde tanımlanmıştır:

Keşişlerin ev yaşamının zevklerinden ve cinsellikten feragat etmeleri, çevrelerindeki toplumdan farklılık duygularını ve düşük yaşam'a dâhil olanlara ahlaki üstünlüklerini gösterdi. Keşişlerin cinsel devamlılıkları olmadan, genellikle gevşek ve ahlaksız hayatlar yaşayanlar olarak anlatılan manastırdan olmayan sıradan insanlardan ayrıldığı görülmektedir. Budist manastır, cinsel arzunun evrensel gücünü kabul etse de onu tamamen ortadan kaldırabilecek bir eğitim programı vaat etti ve ideallerini yansıtanları, en yüksek iyinin peşinde koşan, zevkten vazgeçen kahramanlar olarak gösterdi (2009:111).

Budizm'in evrensel gerçek olarak kabul ettiği cinsellik kavramına dair inanırlarına vaat ettiği şey, kişinin dharma uğruna kendi hazlarından vazgeçerek olarak yolun sonunda bir ödül alacağı sözüdür. Bu hazlardan vazgeçen kişilerin toplumsal olarak sahip olduğu üstünlüğe vurgu yapan Budist düşünce sistemi,

\footnotetext{
Sanskritçe ve Pālicede pārājika (Çince 波羅夷 boluoyi, Tibetçe phas pham pa), manastır yasalarına göre 'yenilgi' anlamında, Saṃgha'dan kalıcı kovulmayı sağlayan kötülükler arasındadır. Rahipler (bhikșu) için dört pārājika suçu vardır: (1) cinsel ilişki, (2) hırsızlık, (3) bir insanı öldürme veya öldürmeye yataklık etme, (4) bir aydınlanma derecesine ulaştığını veya insanüstü güçlere sahip olduğunu iddia etme (uttaramanuşyadharma). Bu dört suçun dışında (5) bir rahibenin köprücük kemiği ile diz arasında bir erkekle fiziksel temastan zevk alması, (6) başka bir rahibenin pārājika suçunu gizleme (7) cinselliği sever bir mizaca sahip olma (şehvet düşkünü bir rahibenin şehvet düşkünü bir adamın gelişine sevinmesi, ondan yanında oturmasını istemesi veya vücudunu ona doğru yakınlaştırması) (8) bir rahibenin keşişliği askıya alınmış birinin ardından gitmesi şeklindedir (Buswell \& Lopez, 2014: 621, $622)$.
} 
cinselliğe dair ağırlı̆̆ını manastır üyelerine verse de sıradan insanlar için bile bunun değerli bir özveri olduğunu da savunmaktadır.

Klasik Budizm'in aksine, Mahāyāna mezhebinin ortaya çıkışı, bazı yeni toplumsal cinsiyet kavramlarını ve daha önceki fikirlerin güncellendiğini göstermektedir. Mahāyāna düşüncesinde kadın cinsiyetinin bir dereceye kadar yeniden değer kazandığı söylenir. Buswell'e göre, özellikle Budist meslekten olmayan kadınlar, bazen Budizm'i besleyen eşler ve anneler olarak idealize edilirler veya kadınsı güzellikleri ve doğurganlıkları nedeniyle övülmektedirler. Ancak kadınlar ister güzellik olarak ister bir fahişe olarak şeytanlaştırılsın, bunlar dharmanın kadına dair görüşünü tam olarak olumlu bir seviyeye çekmez (2004: 303).

\subsection{Tibet Budizmi'nde Cinsellik}

Tantra geleneği aslında, MS. III. yüzyılda, özellikle kuzey Hindistan'da, Vedik kurban, yoga ve kabile uygulamaları dâhil olmak üzere çeşitli fikirlerden gelişmiştir. Tantrik Budizm, Mahāyāna'nın bir kolu olsa da, zamanla manastır ortamının dışına çıktı ve aşkın bilgeliği ve aydınlanmayı arayan çeşitli ritüel ve uygulamalarla Budizm'in kapılarını öğreti teknikleri ve cinsellik gibi yeniliklere açtı.

Cinsel arzu, bir sevgi bileşenidir ve tüm sevgi, aydınlanmanın ortak unsurlarından biri olarak, bilgelik ve merhametin bir tezahürüdür (Blofeld, 1992: 227). Temeli Hindu sistemine dayanan ve VII. yüzyılda Tibet'te beliren Tantrik akım, cinselliği erkek ve kadın arasında beliren birleşme neticesinde bir mutluluk olarak görmektedir.

Gordon White, Tibet Budizmi'nde kökeni Hindu Tantra sistemine giden cinsel birleşme kavramının temel fikrini şu şekilde göstermektedir:

Erken Hindu Tantralarında cinsel ilişki, genellikle Tantrik tanrılara sunu olarak verilmesi amaçlanan cinsel sıvıları üretmenin pratik bir yoluydu. Başka geleneklerde, Tantrik inisiyasyonun ve uygulamaların kalıı bir biçiminin, bir erkek ile bir kadın eş arasındaki cinsel sıvılardaki alışverişler olduğu da söylenmektedir. Tantra fikrinde erkek, üreme ile bir klanı oğluna dönüştürmenin bir yolu olarak bazen erkek guru ya da lamanın menisiyle, birlikte kadın eşinin cinsel sıvıları ile kadını fiziksel olarak tohumlar. Burada dişinin rolü hayatidir, çünkü klan sıvısı (kuladravya) veya klan nektarı (kulāmṛta), vulval öz (yonitattva) veya aydınlanma düşüncesi (bodhicitta) kadının rahminden akar. Dişinin kendisi tanrılık enerjisinin vücut bulmuş hâli olduğu için, cinsel sıvı salgısı ya da âdet akıntısı, tanrıllğın ya 
da aydınlanmış bilincin kendisi olarak kabul edilir. Bu nedenle, Tantrik sekste başlangıçta cinsel sıvılar üretme, sunma ve yutma şeklinde hedeflendi. Ancak daha sonra, amacın bir aracı olarak cinsel orgazm kavramını ön plana alarak mutluluğun kendisi olarak görüldü (2000: 16).

Gordon White tarafından dile getirilen bu görüşlerden hareketle, cinsel birleşme, çok erken dönemlerde kabul törenlerinde tanrılara sunular sunma olarak düşünülmüştür. Hindu Tantralarında görülen cinselliğe dair bilgiler, Budist düşünce sistemi içerisinde Tantrik Budizm ile değer kazanmıştır. Bu değer kazanmanın ilk yansımaları, Guhyasamāja'nın”2, girişinde yer alan “Böyle işittim. Bir zamanlar Bhagavan, tüm Tathāgathaların bedeninin, konuşmasının ve zihninin özü olan kadınların vajinalarında ikamet ediyordu." (Gendun Chopel, 2018: 135, 137) ifadesi ile görülmektedir. Bu giriş kısmı, Bhagavan olarak adlandırılan varlığın metafor olarak kadın vajinasına yerleştirilmesinin Buda bilgeliğini temsil etiğini göstermektedir.

Buswell, Vajrayāna ya da Tantrik Budizm özelinde cinsel birleşme fikrini, cinselliğe bakış, fizyoloji ve aydınlanma kavramları temelinde şu şekilde açıklamıştır:

\begin{abstract}
Vajrayāna Budizmi, cinsiyet kategorisine yaptı̆̆ı vurguyla hem ana akım hem de Mahāyāna geleneklerinden ayrılır. Cinsiyet, merkezî bir hâle gelir. Nihâ̂ aydınlanma hedefini üretmek için erkek ve kadın niteliklerinin birliğini içeren toplumsal cinsiyet sembolizmi Tantrik Budizm'de, güç kazanır, özellikle tantraların en yüksek ve en ezoterik sınıfı olan Anuttarayoga'da cinsel bir anlatım vardır. Bu metinler, dişinin (lotus) prajña veya bilgeliği, erkeğin (vajra) upāya veya becerikli yöntemleri temsil ettiğini ve erkek-kadın cinsel birliğinin yansıtıldığı bir cinsel sembolizm ortaya koyar. Tantrik sanatta, bu genellikle Budaları ve Bodisattvaları kadın eşlerle cinsel birliktelik içinde tasvir ederek gösterilir. Belki de tantrik uygulamaların en çarpıcı yönü, özellikle daha önce bahsedilen cinsel yoga ile bağlantılı olarak, kadınların ritüellere katılımının yaygınlığıdır. Tantrik literatürde, kadınlar genellikle başarılı tantrik uygulayıcılar ve tantrik tekniklerin öğretmenleri ve kurucuları olarak kabul edilir. Hindistan'daki Prenses Laksmnkara veya Tibet'teki Ye shes mtsho rgyal gibi kadınlar, saygın tantrik gurular olarak da hatırlanır $(2004: 305,306)$.
\end{abstract}

Buswell tarafından dile getirilen bu görüşler temelinde ilerlersek, Klasik ya da Mahāyāna Budizmi'nin aksine, Tibet Budizmi'nde aydınlanmaya dair yolların

\footnotetext{
Guhyasamāja Tantra, 'Gizli Meclisin Tantrası' anlaminda kısmen Sarvatathagata-tattvasamgraha'dakiler gibi daha önceki malzemelerden türetilen, ancak açıkça cinsellik gibi yeniliklere sahip on sekiz bölümlü bir anuttara-yoga-tantra'dır (Keown, 2003: 103). Bu eser, müstehcen cinsel görüntüler içerdiği bilinen ilk tantradır. Bu eseri, hem Guhyasamäja çizgisinde hem de içsel bir ruhsal fizyoloji olan cinsel yogadan daha fazla yararlanan ve cinselliğin rolünü vurgulayan Hevajra Tantra gibi metinler izlemiştir (Keown, 2003: 292).
} 
güncellendiği, bilinen dharma ilkesi ile cinsellik gibi sıradan ama gerçek yaşamı var eden unsurların biraraya getirildiği görülmektedir. Tibet Budizmi'ne göre, nihaî aydınlanmanın temel hedefi, erkek ve kadın varlığının birliğine dayanan cinsel birleşmenin çeşitli sembollere (vajra, lotus) belirli anlamlar (bilgelik, şefkat, yöntem vb.) yüklemekle gerçekleşmesidir. Tibet Budizmi'ne kadar kadına verilen değerin ve tehlikeli bir varlık olarak Māra ile eşdeğer olduğu inanışı, Tantrik Budizm ile ortadan kaldırılarak kadının daha merkezî bir rolde, çeşitli ritüel ve uygulamalarda başkarakter olarak partneri ile birlik içerisinde olduğu, sevgi temelli haz duygusunun cinsel birleşme zemininde öğretisel mutluluğa yol açtığı fikrini ortaya koymuştur. Kadına dair bu güncelleme, aynı şekilde yine Buswell tarafından şu şekilde ortaya konmuştur:

Tibet'te erkek uygulayıcılara, kadın partnerlerini tanrıça olarak görmeleri ve onlara hizmet etmeleri ve onlara tapınmaları talimatı verilir. Kadınlar kendiliğinden aydınlanmış bilgeliğin kaynağı olarak bilinmektedir. Yüksek tantrik uygulamaların temel ilkelerinden biri, toplumsal tabuları kasıtlı olarak ihlal edip (cinsel ilişki, et yeme ve alkol içme) sosyal sözleşmeleri yıkarak tüm dualist düşüncelerin üstesinden gelmektir. Bu perspektifle, kadınların saf ve bir tanrıça gibi değerlendirilmesi, kadınların aşağı ve saf olmadığı şeklindeki geleneksel fikri yıkmasını sağladığı için çok etkilidir (Buswell, 2004: 305, 306).

Klasik ve Mahāyāna Budizmi'nin aksine, kadına verilen değerin, yüklenen sembolik görevlerin anlatımı olan bu bölümde, önceleri saf bir vücuda sahip olmayan, âdet görmesi bile bir kirlilik olarak görülen kadının Tantrik Budizm ile artık özellikle ritüel ve uygulamalarda ilah konumuna eriştiği anlaşılmaktadır. Ancak, bu durumun yani kadına yüklenen merkezî rolün sembolik bir durum mu yoksa gerçek bir konumlandırma çabasının ürünü olarak algılanması gerektiği üzerine tam bir görüş bildiremeyiz.

Tantrik Budizm'de aydınlanma ve dharma yolunda yürüyen inanırlar, cinselliğe dair görüşlerini felsefî ve gerçekçi bir zemine oturtur. Bu görüşler, Peng vd. tarafından şu şekilde ifade edilmiştir.

Tantrik inanırlar, varlıklarda ve nesnelerde var olan her şeyin temel boşluğunu kavramasından, tüm ikiliklerin olumsuzluğunu, erkek ve kadın kavramının ötesine geçmekten kaynaklanan yüce mutluluğun cinsellikle deneyimleyebileceğine inanırlar. Cinsel birleşmeler, sıradan insanlara heyecan, zevk ve haz sağladığından, Tibet Budizmi orgazm durumunu ilaç tedavisi için en iyi ilaç olarak görür. Nāropā tarafından bu durum şöyle açıklanır: 


\section{J(৫)}

“(...) orgazm sırasında (cinsel birleşmede) ortaya çıkan bilincin üç niteliği vardır. Bunlardan ilki, büyük bir zevk veya mutluluk duygusudur. İkincisi, mutlak parlaklık veya berraklıktır. Üçüncüsü, her şeyi kapsayan bir dualitesizlik veya ayrılıksızlık duygusudur. Tantrik meditasyon yapanlar, hızlı kurtuluşlar ve aydınlanmalar için bu üç faktörü kullanmaktadır" (Peng et al., 2020: 53, 54).

Dharma ilkesine ters düşen ve dharma kavramının içselleştirilmesini engelleyen ikilikleri ortadan kaldıracak ve boşluk kavramını yansıtacak eylem, yapılması fiziksel ve ruhsal mutluluğa sebep olan cinsel birleşme kavramıdır. Bu doğrultuda, Hintli filozof Nāropā tarafından da dile getirilen cinsel birleşmenin sonucu olarak beliren mutluluk, Tibet Budizmi'nin ritüellerle zenginleşen yenilikçi dünyanın yansımalarını içermektedir.

Tibet Budizmi'nin Budizm'e getirdiği yeniliklerden biri de, aydınlanmayı kaba tabirle kestirme yoldan getirecek öğreti tekniklerine sahip olmasıdır. Bu teknikler, meditasyon merkezli uygulamalarda mantralar, dhāraṇiler, mudrālar ve mand dalalar kullanmaktan ileri gelmektedir. Peng ve arkadaşları, bu durumla ilgili olarak Tibet Budizmi'nin görselleştirmeye başvurmasına değinmektedir:

Tibet Budizmi, diğer Budizm ekollerinden farklı olarak, fazlasıyla görsel temsiller aracılığıyla Tantrik ritüellerde 'aydınlanmış beden' olma potansiyeline sahip olarak fiziksel beden formunu yenilikçi bir şekilde ifade eder. Örneğin, Vajradhara, Śākyamuni'nin kişileştirilmiş formu olarak olarak eşi Tilottama $\vec{a}$ yı kucaklar duruşta, lotus pozisyonunda oturan iki kollu biri olarak tasvir edilir. Tibetli uygulayıcılar için, bu cinsel imgelerle uğraşmak hem zihin hem de fiziksel seviyelerde cinsel bir eşle meditasyon yapmak, zihinbeden eylemlerini büyülü hâle getirmek için bir yöntemdir. Ayrıca Tantrik inanırlar, Vajradhara ve eşinin bu imajına yönelik görünümünü bir kenara bırakıp bunun aşkın bir sekse dönüşebileceği ve bunun tersinin de olabileceği bir fikre de sahipti. Böylece seks ya da cinsel birleşme, kutsallığa ulaşır ve beden, bu kutsallığın tapınağı hâline gelmektedir (2020: 53).

Peng ve arkadaşları tarafından görselleştirmeye dayanan bu tekniğe dair görüşlere ilave olarak Blofeld de değerlendirmelerde bulunarak cinsel birleşme temelli aydınlanma kavramına değinmektedir.

Tantrik sanat, cinsel ilişkide bulunan çiftlerin ve bazen daha büyük grupların temsilleriyle doludur ve çoğu Tantrik metin, cinsel pratikle ilgili uzun tartı̧malar da içerir. Śiva, Vajrasattva ve bunlar dışında bir dizi başka doğaüstü varlığın aslında kadın organının içinde yaşadığı ve eşleriyle cinsel ilişkiye girdikleri bilinen bir durumdur. Tantrik uygulayıcı, dünyevi insan düşüncesini aydınlanmış tanrı bilinciyle değiştirmek ve cinselliği aydınlanmaya giden bir ilahî yol olarak görmektedir. Bazı maṇdalalarda, Jinnalar ${ }^{3}$, beş tür

3 Jina olarak da yazılan Sanskritçe Jina terimi, Budalar için kullanılan, 'galip, muzaffer' anlamına gelen bir unvandır. Bu terim, aydınlanma (bodhi) aracıllğıyla bir Buda'nın varlıkları saṃsāra'da tutsak tutan 
bilgelik ile etkileşime giren enerjiyi temsil etmek için yab yum formunda gösterilir (Blofeld, 1992: 110).

Tibet Budizmi'nde cinselliğe dair ekollerden biri de, fizyoloji temelinde görülen kanallar ve cakra sistemleri üzerinedir. Chopel, bu doğrultuda, cinselliğin fizyolojik yönünü sistematik şekilde ortaya koyan Tsong kha pa (13571419) örneğiyle Tantrik seks kavramını açıklamaktadır:

Geluk mezhebinin kurucusu olarak kabul edilen Tsong kha pa (1357-1419) bir dizi eserinde cinsel yoganın kullanımı üzerine bilgiler vermiştir. Onun görüşlerinin altında yatan sebep, insan fizyolojisine dair özel bir tantrik görüşün olmasıdı. Bu tantrik fizyolojiye göre, rüzgârlar (prāna) veya süptil ${ }^{4}$ enerjiler, bedende yetmiş iki bin kanaldan (nāḍi) oluşan bir ağda akar. Bu rüzgârlar, bilinç için görev yapar. Tüm bu kanallar arasında en önemlisi, cinsel organlardan başın tepesine kadar uzanan, daha sonra aşağı doğru kıvrılarak gözler arasındaki boşlukta sona eren merkezi kanal avadhūtì'dir. Merkezî kanala paralel olan sağ ve sol kanallar, rüzgârın merkezi kanaldan geçmesini önleyen daralmalar veya düğümler oluşturur. Bu daralma noktalarında, vücuda yayılan daha küçük kanal ağları da vardır. Bu noktalara cakra denir. Bunların sayısı, genellikle yedidir. Bunlar, alında, başın tepesinde, boğazda, kalpte, göbekte, omurganın tabanında ve cinsel organların açıllığında yer almaktadır. Geluk sisteminde Tantrik pratiğin en üstün biçimi ve Budalı̆̆ı getiren tek uygulama biçimi olarak arzuyu yola sokmak yani 'bilgelik eşi' denen varlıkla cinsel ilişkiye girmektir. Bu sistemde, cinsel birleşme olmadan Budalığa ulaşmanın imkânsız olduğu ve Śākyamuni de dâhil olmak üzere geçmişin tüm Budalarının bu şekilde Budalığa ulaştığı söylenmektedir (Chopel, 2018: 135, 137).

Verilen açıklamalar temelinde, fizyolojik olarak çeşitli görüşlerle desteklenen Tantrik seks kavramı, Tibet Budizmi sistemi içerisinde hem aydınlanma hem de Budalığa ulaşmak için gerekli bir yöntem olarak kabul görmektedir.

\subsubsection{Tibet Budizmi'nde Cinsellik Sembolleri}

Bu başlık içerisinde tespit edebildiğimiz, cinsellik sembolleri dhvajā, vajralotus ve yab yum'dur. Bu kavramlar, ağırlıklı olarak meditasyona dayalı uygulamalarda hem yazılı olarak hem de görsel olarak resim ve heykellerle temsil edilmektedir.

tüm olumsuz güçleri fethettiği gerçeğine atıfta bulunur. Bunlar genellikle şeytan, Māra figüründe sembolize edilir ve Buda'nın Māra üzerindeki zaferi Budist sanatta popüler bir temadır. Ayrıca, bu ifade Mahāyāna ve Tantrik Budizm'de Beş Meditasyon Budası terimini içermektedir (Keown, 2003: 126).

4 İngilizce subtle teriminin Türkçe karşılığıdır. Terim, 'ince' ya da 'yarı ince' anlamında daha çok madde kavramını anlatmaya yarayan bir sözcüktür. 


\section{ग(৫)}

\subsubsection{Dhvajā}

Sanskritçe dhvajā terimi, metafor olarak Sanskritçe lingā ya da lingam 'penis' kelimesi ile eş anlamlı olup Śiva'nın bayrağı olarak bilindiği gibi, 'erekte olmuş erkek penisi' olarak da görülmektedir (Beer, 1999: 180).

\subsubsection{Vajra-Lotus}

Tarihsel olarak vajra hem bir silah hem de bir asaydı. Bir asa veya kraliyet sembolü olarak vajra, merkezî bir eksen üzerinde birleşen dört çatallı kemerli halkalarıyla, Avrupadaki kralların taçlarına benzemektedir. Bilgeliği simgeleyen ve kadın elinde tutulan ghanțā ile birleştiğinde, vajra, yöntem ve bilgeliğin ya da becerikli yöntemler ve ayırt edici farkındalığın mükemmel birliğini temsil eder. Cinsel bir sembol olarak vajra, penis-vajina birliği içinde bir metafor olarak lotus ile birleştirilir (Beer, 1999: 233).

Tibet Budizmi'nde, Gray'e göre, cinsel sıvıların yutulması uygulamasından çok sayıda tantrik yorumcu bahseder, bazen metafor olarak penise 'vajra' ve vajinaya 'lotus' olarak atıfta bulunduğu bilinen bir durumdur. Bu uygulama hakkında Cakrasamvara Tantra yorumcusu Kambala "lotus yuvası, meni ve rahim kanının karışımıyla dolu olduğundan, özellikle öpülmeli ve dille emilmelidir. Vajra ve lotusu, bu siviyı içmenin coşkusu ile birleştiriniz." (Gray, 2007: 118) açıklamasını yapmaktadır.

Vajina ve penis kelimelerinin karşılıklarına bakıldığında, vajina kelimesi, Sanskritçe yoni ve bhaga ifadelerine denk gelmektedir. Bu terim, Tibetçede $b+h a$ ga, skye gnas 'doğum yeri’ (Hopkins) ve Çincede 腔 zhì, 陰道 yinndào ve 陰穴 yinnxué 'vajina' (Chinese English Pinyin Dictionary, vagina maddesi) karşllıklarına sahiptir. Ayrıca, sembolik olarak lotus çiçeğinin vajina görünümü vardır. Beer, bu durum için, "bir lotustan doğum, kusursuz bir gebeliği ve doğan varlğın doğuştan ilahi olduğunu ve karmik kusurlardan etkilenmediğini gösterir. Böylece lotus, ilahi bir rahim olarak güçlï bir cinsel metafordur. Sanskritçede lotus anlamina gelen padma ya da kamala vajina'nın eş anlamlısıdır" (1999: 37) açıklamasını yapar. Penis kelimesi ise, Sanskritçe lingā ya da lingam (Beer, 1999: 258) ifadesine denk gelmektedir. Tibetçede gnas (Hopkins) ifadesi ile de görülen penis sözcügüu, Çincede 卵子 luănzi, 帛 diăo, 陰荎 yīnjīng, 陽具 yángjù, 陰徑 yìnjìng, 㞠 liáo, 陽物 yángwù 'penis' ifadelerine karşllık gelmektedir. Buswell ve Lopez'e göre, vajra, Tibet 


\section{0}

sembolizminde, erkek penisinin eş anlamlısıdır, sert ve nüfuz edici görünümdedir. Vajra ve lotusun birliği, ilahî kucaklamada mutlulukla birleşen, form ve boşluğun, şefkat ve bilgeliğin birliğinin cinsel bir metaforudur. Cinsel birleşmenin içsel sembolizmi, bedenin merkez kanalına giren ve yükselen ve her bir kanal çarkının lotusunu delip onların açılmasına neden olan psişik rüzgârlara atıfta bulunur (2014: 37).

Beer, vajina ve penis temelinde, bu sembolleri metaforik bir cinsel sembolizm olarak kabul eder. Beer'e göre:

\footnotetext{
“Yoga Tantra'da Sanskritçede chaturananda karşıllığında dört neşe vardır. Dört sevinçten ilki 'neşe' (Sanskritçe ananda) olarak bilinir ve penisin vajinaya girişini sembolize eder. İkinci sevinç 'mükemmel neşe' (Sanskritçe paramananda) cinsel ilişkinin süresini ve daha fazla neşe ya da tutkulu zevk arzusunun ortaya çıkışını temsil eder. Üçüncü sevinç 'neşenin kesilmesi' (Sanskritçe viramananda) orgazmı ve artan tutkulu dürtünün kesilmesini temsil eder. Ve dördüncü sevinç 'doğuştan gelen sevinç' (Sanskritçe sahajananda), orgazmın sonradan ortaya çıkan ve önceki neşeden fışkıran mutlu aşkın deneyimini temsil eder." (1999: 330, 331).
}

\subsubsection{Yab yum}

Tantrik inanırlar, aydınlanmaya tek bir yaşamla ulaşılabileceğine inanıyorlardı ve aydınlanma tüm faaliyetlerde bulunabileceğinden, "aile yaşamı, kasabalar, şehirlerin pazar yeri, bir ölü yakma alanının manzaraları ve izole edilmiş vahşi alanlar" gibi yerlerde pratik yaptılar. Tantrikler, bir uygulayıcı ile gerçek veya hayalî kadın eşi arasındaki cinsel uygulamalar da dâhil olmak üzere, insan vücudunu aydınlanma aracı olarak kullandılar. Kadın ve erkek eşleri tasvir etmek için zengin bir terminoloji olsa da, yab yum terimi, Tibetçede baba ve anne için kullanılan onursal sözcüklerdir (Heroldová, 2016: 75).

Hopkins, Tibetçe yab yum teriminin Sanskritçede pitr-mātr ' 'ebeveyn, annebaba' ifadesine denk geldiğini belirtip terim için "bu aynı zamanda bir tanrıya ve onun birlik içindeki eşine de atıfta bulunur." açıklamasını yapar.

Keown, yab yum sözcüğünün temel anlamının 'anne ve baba' olduğunu, terimin Budizm'de erkek ve dişinin cinsel birliğini gösteren bir sembol olduğunu ifade eder. Budist ikonografilerde bu birliktelikte erkeğin şefkatle (karuṇā) ve becerikli yöntemlerle (upāyakauśalya) kadının ise içgörüyle (prajña) bağlantılı olduğu söylenir (2003: 338). 


\section{ग(৫)}

Yab yum, Hindistan, Nepal ve Tibet Budist sanatta, erkek tanrının kadın eşiyle cinsel kucaklaşmadaki görüntüsü demektir. Bu temsildeki poz, genellikle, aktif kuvvetin veya yöntemin (eril olarak algılanan upāya), bilgelikle (dişil olarak algılanan prajña) mistik birliğini temsil eder. Genellikle erkek ve kadın Budalar, Bodisattvalar ve koruyucu varlıklarla gösterilen temsiller, dünyadaki sahte ikiliğin üstesinden gelmek için gerekli ruhsal aydınlanma yolunda çabalamayı yansıtmaktadır. Cinsel birleşmenin mistik birliğin sembolü olarak kullanılması, Hint Tantra düşüncesinden evrilmiştir. Çin ve Japonya Budistleri tarafından hiçbir zaman tam olarak kabul edilmeyen bu sembolizm, Tibet'te, bir tanrıya eşiyle birlikte dua edildiğinde, yakarışların daha etkili kabul edildiğine inanılarak keşişler ve rahipler tarafından benimsenen bir duruştur (Encyclopedia Brittanica, yab yum maddesi).

Yab yum kavramı, 'Indra'nın ağ1 ${ }^{15}$ kavramını kullanarak, benzer iç içe geçme veya birleşme fikri (Tibetçe zung-'jug; Sanskritçe yuganaddha) aracıllı̆ııla kadın eşiyle birlikte bir erkek tanrı olarak tasvir edilen bilgelik ve merhametin ilkel birliğini temsil eden bir duruştur (Neville, 1987: 357). Yab yum'da dişi, erkeğin kucağına oturur, ancak tersine bir şekilde erkek de dişinin kucağında oturur, buna da yum yab denmektedir (Simmer-Brown, 2002: 159).

İkonografilerde Tantrik çiftler, her zaman ayakta veya otururken tasvir edilir. Görüntüler genellikle erkek tanrıyı, kadın eşi kucaklarken, yüzü ona dönükken gösterir. Erkek tanrının elleri çeşitli ritüel aletlerini tutar. Kadın eşin kolları ya ritüel nesnelerini tutar ya da erkek tanrının arkasına gizlenir. Dişi tanrı, erkek tanrıyı genellikle ayakta dururken iki ya da sadece bir bacakla çevreler (Heroldová, 2016: 75). Bu görüntüler, esas olarak meditasyon ve ibadeti desteklemek için bir araç olarak yaratılan Buda Babası ve Buda Annesinin cinsel birlikteliğini temsil eder. Bu görüntüler, erkek ve kadın arasındaki bilinç durumunu ifade etmeye çalışır (Peng et al., 2020: 52).

\footnotetext{
Indra'nın ağı, Indra'nin mücevherleri veya Indra'nın incileri olarak Sanskritçe Indrajwäla karşllığına sahiptir. Budist felsefede śūnyatā (boşluk), pratityasamutpāda (bağımlı oluşum) ve iç içe geçme kavramlarını göstermek için kullanılan bir metafordur (Odin, 1982: 17, Jones, 2003: 16, Lee, 2005: 473).
} 


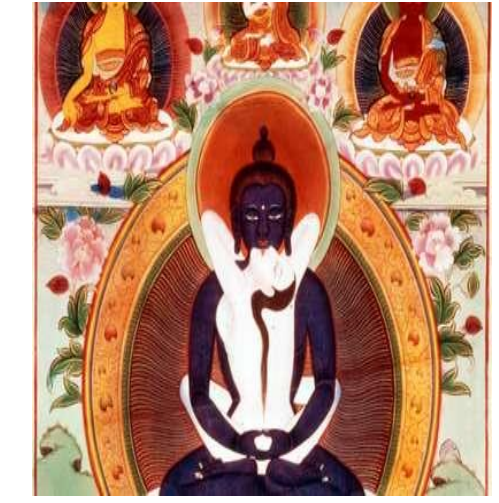

Resim I: Yab yum I

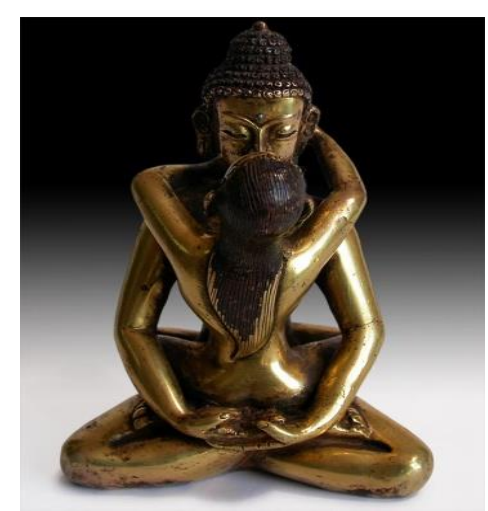

Resim III: Yab yum III

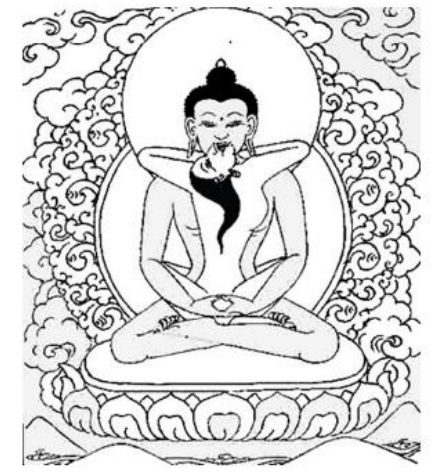

Resim II: Yab yum II

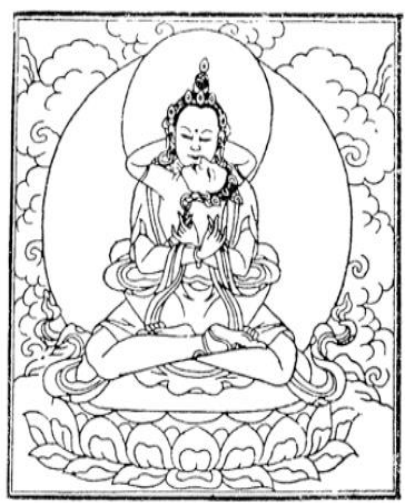

Resim IV: Yab yum IV (Kadın Kadına)

Yukarıdaki yab yum pozlarına bakıldığında, Buda annesi, Tantrik uygulayıcının Buda'nın deneyimlerinde ve düşüncelerinde belirgin olan daha yüksek bir gerçeklik seviyesinin farkına varması için gerekli soyut ve sessiz bilgelik kavramını ve Buda babası ise herkes için şefkati temsil eder. Tantrik Budizm'de bilgelik ve şefkat, Buda annesi ve Buda babasının cinsel birliği üzerine meditasyon yaparak elde edilebilir (Peng, 2013: 36).

Cinsel birliktelik içerisindeki tantrik tanrılar, ikonografilerde ilk kez cinsel kucaklaşma yaşayan 'on altı yaşındaki bakireler' gibi tanımlanırlar ve bir baba ve anne olarak birleşmeleriyle ortaya çıkan mutluluğu yansıtırlar. Ayıca, Budist resimlerde ve heykellerde, penis başının kanla şişmesi, büyük mutluluğa ulaşmayı; vajinanın lotus görünümü gibi açı olması, bilgeliği ve onu çevreleyen doğadaki, boşluğu temsil eder. Bu lotusun klitoris ve vulvayı çevreleyen iki labia kıvrımından oluşan üç yaprağı, üç ana kanalın açıklığını sembolize eder. Bu durum, biçimsizlik ve biçimin evliliğini, bilgelik ve şefkatin birliğini ve boşluğun ve büyük mutluluğun birbirini tamamlamasını sembolize eder (Beer, 1999: 140). Ayrıca, yine Budist ikonografilerde yab yum'daki tanrılar, cinsel ilişki için kaplan postu peştamallarını gevşetirler. Bu gevşeme, fenomenlerin dış nesne ve 
kavramsal düşüncenin iç özne olduğuna dair dualist inancın bir kenara atılmasını sembolize eder. Gevşemiş kaplan postu, tanrının dört Māra'nın üstesinden gelme cesaretini ve onun özne ve nesne kavramını reddetmesini veya bir kenara atmasını temsil eder (Beer, 1999: 316).

Son olarak, Tantrik eserlerdeki cinsel sembolizmin, Tibetliler arasında yüce amaçlara hizmet etmek için dönüştürülebilir olduğu gerçeğinden hareketle, Tibet'te, yab yum teriminin gösterdiği tanrıların temsillerine büyük saygı gösterilir; ruhsal coşkunun yanında en yüksek mutluluğun kaynağı olan fiziksel bir cinsel birleşmenin bilgelik ve şefkat güçlerinin birliği olduğu da düşünülmektedir (Blofeld, 1992: 72).

\section{Tantrik Türk Budizmi'nde Yab yum Sembolizmine Dair Tanıklar}

Tantrik Türk Budizmi, Moğol-Yuan Hanedanlığı hâkimiyeti altındaki Uygurların Tibet Budizmi etkisinde geliştirdikleri dinî edebiyatın adıdır. Tantrik Türk Budizmi, ${ }^{6}$ bünyesinde Tibet Budizmi ile kendisini gösteren çeşitli ritüel ve uygulamaları, büyülü sözleri ve meditasyonu barındıran ve XIV. yüzyıla tarihlendirilen bir dönemdir.

XIV. yüzyıla kadar Soğd, Tohar ve Çin Budizmi'nin etkisinde gelişen Uygur Budizmi, XIV. yüzyılda Tibet Budizmi'nin temelinde var olan aydınlanma fikri doğrultusunda, aydınlanmayı kısa yoldan meditasyon ve yoga yaparak hedeflemiştir. Uygurlar, özellikle maṇdala ve mudrālarla meditasyona girerek dhāraṇi denilen büyülü sözler söylemiş, meditasyonu tamamlayıp başta Buda aydınlanması olmak üzere, uzun yaşam, hastalıktan kurtulma, iyi formda yeniden doğum vb. faydalar elde etmeyi amaçlamıştır. Bu faydalar, ağırlıklı olarak öğreti hocaları olarak bilinen Guruların başlattığı ritüellerle görülmekle birlikte, Budalar, Bodisattvalar, Tanrıçalar ve Koruyucu ilahlar (yidamlar) gibi kişilikleri, ritüellere dâhil ederek de gerçekleşmiştir. Bu yönüyle, çeşitli araştırmalarla Uygurlarda derin etkiye sahip olduğunu gördüğümüz Tibet

\footnotetext{
Uygurların Tibet Budizmi'ne dayalı geliştirdikleri dinî edebiyat üzerine kapsamlı bilgiler, bu sahanın kültürel arka planı üzerine değerlendirmeler için bk. Ölmez, M. \& Uzunkaya, U. (2017). Eski Uygurcada Tibet Budizmi. Türk Dili Araştırmaları Yıllığı Belleten, 65(1), 61-89; Uzunkaya, U. (2020). Budist Eski Uygur Edebiyatından İki Metin. İstanbul: Kesit Yayınları; İsi, H. (2020). Tantrik Türk Budizmi Üzerine Araştırmalar. Uluslararası Sosyal Araştırmalar Dergisi, 13(72), 111-124; İsi, H. (2021). Eski Türkçe Tantrik Bir Metin: Usnīsa Vijayā Dhāranī Sūtra. Ankara: Türk Dil Kurumu Yayınları.
} 


\section{ग(৫)}

Budizmi, Türk Budizmi'nin yeni istikameti olarak Gurular, Budalar, Bodisattvalar, Tanrıçalar ve Koruyucu ilahlar liderliğinde büyüye ve meditasyona dayalı bir dinî gelenek olarak sadece inanç noktasında değil, özellikle blok baskı tekniğini kullanma, Budizm'in orijinal kaynaklarına yönelme, Tibetçeden çeviriler yapma gibi yenilikleri de bünyesinde barındırarak birçok açıdan araştırmacılara bu sahaya dair incelemeler yapma firsatı vermektedir (Porció, 2003: 88, 89).

Tibet Budizmi'nin Budist Uygurlardaki yansımaları, dişi tanrıların ve kadın Bodisattvaların ritüel ve uygulamalarda merkezî rolde olması, meditasyon yapma, büyülü sözler kullanma, çeşitli el-kol hareketleri yapma (mudrālar), kutsal daireler (mandalalar) ve Tantrik seks özelinde cinsel birleşmeyi yansıtan cinsel kucaklaşma gibi kavramlarla görülmektedir. Bu yansımalar arasında çalışmamızın da konusunu oluşturan kavramlardan biri, özellikle Budist sanatta resim ve heykellerde cinsel birleşme yaşayan Buda annesi ve Buda babası pozunu gösteren Tibetçe yab yum sembolizmidir. Tibetçede yab yum olarak bilinen cinsel kucaklaşma, önceki bölümlerde zikredildiği üzere, erkek ve kadın arasındaki zıtlıkların birleşimi olarak şefkat, bilgelik ve upāya denen yöntemle aydınlanmayı ve Budalı̆̆ hedefleyen Tibet sembolizmini yansıtmaktadır.

Tibet kökenli yabyum ifadesini yansıtan Eski Uygurca ifadelere bakıldığında, ög kay ifadesi 'anne baba' anlamında Tantrik Uygur metinlerinde 'bir tanrı olarak Tibetçe yab yum' ifadesine denk gelmektedir (Wilkens, 2021: 523). Terim, Çincede 父母 fümǔ (Chinese English Pinyin Dictionary, 父母 maddesi), Sanskritçede pitrmātr (Hopkins) karşılığına sahiptir. Eski Uygurca ög t(e)yri ‘Tanrıça' (Uçar, 2013: 272) ifadesi, Sanskritçede devī (Thurman, 2010: 603, Hopkins), śrïdevī (Jordan, 2004: 172), Çincede 女神 nüshén 天仙 tiānxiān (Chinese English Pinyin Dictionary, goddess" maddesi), Tibetçede btsun mo (Hopkins), lha mo (Thurman, 2010: 603, Tucci, 1980: 309), yum (Müller 1928: 384) ve Moğolcada dagini 'tanrıça, ilahe, güzel kadın' (Lessing 2017: 289), emegelci 'Tanrıça, evin koruyucu perisi' (Lessing 2017: 395), öm-e ‘tanrıça, ilahe’ (Lessing 2017: 770) karşılıklarına sahiptir. Son olarak kuç- ve kuçmak sözcüklerine bakıldığında, kuç- 'kucaklamak, sarılmak, sımsıkı, sarılmak' (Wilkens, 2021: 418) anlamındadır. Eylemle alakalı türetilen biçimler ve kullanımlara bakıldığında, kuça tut- 'sıkıca kucaklamak', kuçmak 'kucaklama, sarılma', kuçakla- 'kucaklamak, içine almak', kuçugsa- 'kucaklamak istemek', kuçumsın- 'sözde sarılmak, sarılıyormuş gibi yapmak', kuçuş- 'kucaklaşmak' (Wilkens, 2021: 418) gibi türevlerin olduğu görülmektedir. 
Tibet sembolizmi içerisinde vajra 'penis' ve lotus 'vajina' birliği ile eş anlamlı Tibet kökenli yab yum, Budist Uygurlarda ög kay, ög t(e)gri kızı, kuç- ve kuçmak sözcükleri ile görülmektedir. Zikredilen bu terimler, bir bütün içerisinde Tibetçe yab yum ifadesini karşılamaktadır. Aşağıda tanıkladığımız metinler, Tibet Budizmi'ne dayalı Budist Uygur metinlerinde ög kay ifadesinin tek başına 'Buda annesi ve Buda babası' anlamını yansıtmadığını ancak ög kay, ög t(e)gri kızı, kuçve kuçmak ifadeleriyle Tibet kökenli yab yum cinsel sembolizminin yansıtıldığını göstermektedir:

(1) kèruka ög kay ikigünüy etözlerinte v(a)çir-a satv-a tört ornagtakı dèvatalarnı töpötelerinte ratna-sanbave köyül tilgeninteki dèvatalarını törülerindeki akşobe til tilgenteki dèvatalarını töpölerinte abita etöz tilgenteki dèvatalarnı töpölerinte varyoçana tangarıg tilgendeki devvatalarnı töpölerinte amogasiti burhan bolmışların sakıngu ol "Heruka'nın Anne ve Baba formunun bedenlerinde Vajrasattva, dört bölgedeki Devatālarda Ratnasambhava, gönül cakrasındaki Devatālarda Akṣobhya, dil cakrasındaki Devatālarda Amitābha, vücut cakrasındaki Devatālarda Vairocana, adak (sunu) cakrasındaki Devatāların tepelerinde Amoghasiddhi olduğunu düşünmelidir." (Kara \& Zieme, 1976: 36, 37).

(2) sol adakın yıgip kara öglüg maheşvaréni tepe turur bir yü̈̈zlüg iki kollug üç közlüg on èligi üze $v(a)$ çirig tutup sol èligi üze çanıg tutup ög t(e)pri kızın kuça tutar "Heruka, sol ayağını ona atıp kara renkli Maheśvara'yı tekmeler. Bir yüzlü, iki kollu üç gözlü sağ elinde vajra, sol elinde çan tutup Devatālar annesini kucaklamaktadır." (Kara \& Zieme, 1976: 49).

(3) çakira sanbara ög kannı burhanlar bodis(a)t(a)vlar üze kurşatılu turur "Buda ve Bodisattvalar, Cakrasaṃvara'yı çevrelemektedir." (Kara \& Zieme, 1976: 51,52).

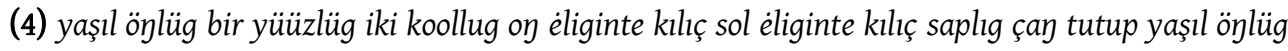
yéel m(a)habutug erksinmeklig ayadura burhan ögin kuça turur "O, yeşil renkte, tek yüzlü ve iki kolludur. Sağ elinde bir k1lıç ve sol elinde bir zil tutar. Ve o, rüzgâr elementini (Mahābhūta) kontrol eden yeşil renkli tanrıça (Buda Annesi) Ayadura'ya sarılır" (Kara \& Zieme, 1976: 71).

(5) (...) ög t(e)yri kızı (...) yér m(a)habut arıgu buda (...) sarıg öylüg on èliginde navaskart sol èliginde kapala tutup kaynı kuçmak (...) yay üze olorur térin kuvrag altmış tört t(e)yri kızları ol ok yaylıgın taşgarı karşayu turur barça erdinite ulatı beş şantiklerke tükellig sakıngu ol “(...) tanrıça kızları (...) toprak elementinin safllğı (...) sarı renklidir. Sağ elinde bir bıçak, sol elinde bir kafatası tutup babasını kucaklayıp (...) bu şekilde oturur. Altmış dört Tanrı kızları da bu kalabalıkta ortaya çıkıp etrafını sarar. Tüm mücevherlerin ve beş śāntika'nın bunların bir parçası olduğunu hayal etmek gerekir" (Yakup, 2016: 147).

(6) kizleg oronta kişe užèk işnin arıgı amogasidi burhan yaşıl önlüg on èliginde kilıç solında kıllı̧ saplıg çay tutar ög t(e)yri kızı yèl $m(a)$ habut arıgı samaya tara ol burhanka okşatı öglüg on èliginde navaskart solında kapala tutup ögin kuça yạ üze oloror térin kuvrag iki kırk t(e)yri kıları "Gizli yerde kșa hecesi bulunur. Buda Amoghasiddhi, yeşil renktedir. Sağ elinde k1lıç, sol elinde bir çan tutmaktadır. Rüzgâr elementinin saflığı olan tanrıça Samaya-Tārā, bu Buda ile aynı renktedir. Sağ elinde, bir kasap bıçağı, sol elinde kafatası tutmakta ve bu şekilde annesini 
kucaklamaktadır. Böylece, Otuz iki ilahi kızın şekli ve birlikteliği ortaya çıkar.” (Yakup, 2016:

147, 148).

Tibet Budizmi'ne dayalı Budist Uygur metinlerinde Buda Annesi ve Buda Babası'nın birbirini kucaklar pozda cinsel birleşme içerisinde gösteren tanıklarına bakıldığında, BT VII A metinin 128-136. satırlarını çeren (1) numaralı metinde, Heruka'nın ${ }^{7}$ anne ve baba formuna atıfta bulunulur:

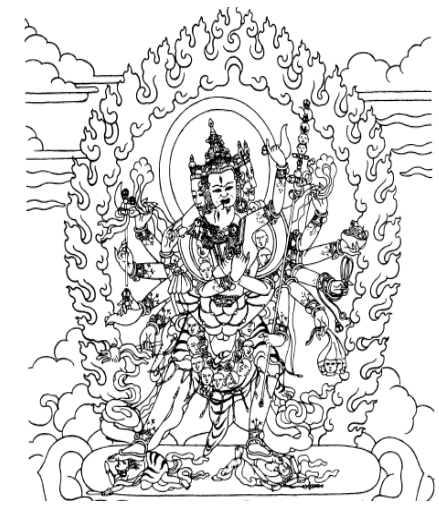

Resim V: Heruka'nın Anne ve Baba Formu (Geshe Kelsang Gyatso, 1997: 238)

BT VII A metinin 128-136. satırlarında Heruka'nın Anne ve Baba formunda dört yön/dört element kavramları özelinde, çeşitli ilahların ve Budaların bu yön ve elementlere göre konumlandırıldığı ve dört cakra sistemi içerisinde temsilleri yer almaktadır. Resim V'te'de görüldüğü üzere, yab yum pozunda gösterilen Heruka formu hakkında Geshe Kelsang Gyatso, şu değerlendirmelerde bulunur:

Ana yönlerdeki dört yogini, bazen dört elementin tanrıçaları olarak adlandırılır çünkü bunlar, dört elementin rüzgârlarından ortaya çıkarlar. Ara yönlerde görselleştirilmiş varlıklar, dört sununun tanrıçalarını sembolize eder: Bunlar, Rupavajra, Gändhavajra, Rasavajra ve Parshavajra olarak görülür. Beş nektarla dolu dört kapala şeklindeki sunu tanrıçaları, kalp cakrasının dört ara kanal yaprağından ortaya çıkar. Bu kanallara sunuların dört kanallı yaprakları denir, çünkü bunlar dört sunu maddesinin biçim, koku, tat ve dokunma gibi rüzgarlarının yollarıdır. Heruka'nın beden mandalasının meditasyonu ve okunması yoluyla, dört elementin rüzgârları ve dört sunu maddesinin rüzgârları, kişiyi saflaştırmaktadır. Bu mandalada, merkezî ilah, Baba Heruka ve Anne Heruka ile ana yönlerdeki dört yogini, 'büyük mutluluk çarkının ilahları' olarak bilinir. Çevrelerinde kalp cakrasının, dil cakrasının, vücut cakrasının ve baba'ya bağlılık cakrasının ilahları vardır (1997: 106, 107).

Heruka, Tantrik Budist geleneğin en önemli tanrılarından biridir ve sistemli ve düzenli bir Tantra metni olan Heruka Tantra, ona adanmıştır. Tek başına ya da Prajñası Nairātmyā ile yab yum pozundadır. Śūnya'nın bir erkek olduğunda Heruka'nın ve kadın olduğunda da Nairātmyā’nın formunu aldığına inanılır. Prajña veya Śáktisi ile kucaklaştığında (yuganaddha, yab yum), Hevajra'nın bir dizi forma sahip olduğu söylenir. Sādhanamālă’da, Heruka'ya tapınmanın, kişiye Budalık kazandırdığı ve dünyadaki tüm Māraları yok ettiği söylenir (Donaldson, 2001: 221). 


\section{因)}

$\begin{array}{ll}\text { Heruka'nın Anne ve Baba Formlu bedeni } & \rightarrow \text { Vajrasattva } \\ \text { Dört yöndeki yoginiler } & \rightarrow \text { Ratnasambhava } \\ \text { Gönül çakrası } & \rightarrow \text { Akṣobhya } \\ \text { Dil çakrası } & \rightarrow \text { Amitābha } \\ \text { Beden cakrası } & \rightarrow \text { Vairocana } \\ \text { Adak (sunu) cakrası } & \rightarrow \text { Amoghasiddhi }\end{array}$

Heruka'nın anne ve baba formlu bedeni özelinde var olan anlatımda Beş Meditasyon Budası sembolizmine de yer verilmiştir. Beş Meditasyon Budası, resim ve heykellerde aynı şekilde temsil edilir, hepsi manastır kıyafetleri içinde, aynı saç modeli ve uzun kulaklarla, kendi karakteristik renkleri, sembolleri, ellerin duruşu ve yüzleri ile birbirinden ayırt edilirler. Beş Meditasyon Budasının her biri için kozmos bölünmüş ve bu ilahlardan yayılımlar ortaya çıkmıştır. Böylece, her biri, bireysel varoluşun yanı sıra kozmik bütünü oluşturan beş skandha'dan birini temsil eder (Encyclopedia Britannica, Dhyani-Buddha maddesi). Ayrıca, Tibet Budizmi geleneğinde altıncı Meditasyon Budası olarak da düşünülen Vajrasattva'da bu anlatımda kendine yer bulmaktadır.

Geshe Kelsang Gyatso'nun değerlendirmelerinden hareketle, Uyguca metne baktığımızda, Heruka'nın Anne ve Baba formlu bedeni özelinde, çeşitli ilahlar ve cakra sistemleri düşünülerek meditasyonla aydınlanmaya ulaşmak istendiği görülmektedir.

BT VII A metninin 399-406. satırları arasında, (2) numaralı metinde, Heruka'nın Anne ve Baba formuna dair bir tasvir görülmektedir. Bu anlatıya göre, Heruka'nın Anne ve Baba formuna bakıldığında, Heruka sol ayağını siyah renkli Maheśvara'ya ${ }^{8}$ uzatıp onu tekmelemekte, bir yüzlü, iki kollu, üç gözlü formda Heruka'nın sağ elinde vajra, sol elinde çan, Devatālar ${ }^{9}$ annesini yani kadın

8 Śiva-Maheśvara, Budist panteona dâhil edilen en önemli Hindu tanrılardan biridir. Öfkeli koruyucular arasında yer alır ve daha sonraki Tantrik Budist gelenekte yogiler ve siddhalar için bir rol model olarak görülür. Maheśvara kültü, Nanbeichao döneminde Çin'e girdi ve bu kültle ilgili ritüeller Tuoluonizaji'de görülür. Maheśvara kültü ile ilgili kutsal metinler arasında, 摩䤈首羅天法要 Moxishouluo tian fayao ‘Tanrı Maheśvara'nın Temel Yöntemleri’ ve 摩䤈首羅大自在天王神通化生伎 藝天女念誦法 Moxishouluo dazizai tianwang shentong huasheng jiyi tiannü niansong fa 'Kendinden Var Olan Büyük Kralın Śrīdevī'nin Büyülü Dönüşümü Maheśvara'yı Çağırma Yöntemleri’ adlı ritüel metinleridir (Sørensen, 2011: 116).

9 Sanskritçe ve Pālicede, soyut olarak göksel varlıkların veya tanrıların (deva) tüm sınıflandırmalarına atıfta bulunan devatā 'tanrı olma durumu' terimi ile verilir. Tapınılan veya adak sunulan herhangi bir 


\section{J(O)}

partnerini kucaklamaktadır. Uygurca metne göre, anlatılan Heruka'nın Anne ve Baba Formu'nu aşağıda yer alan temsille daha net görebiliriz.

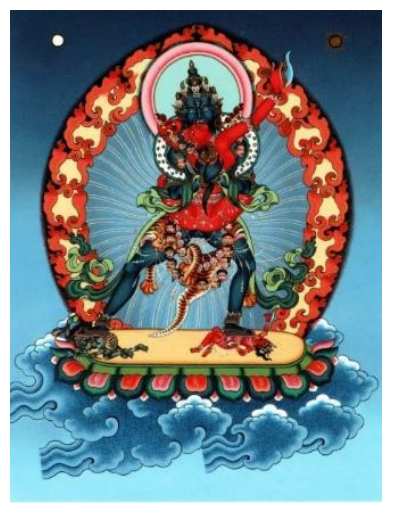

Resim VI: BT VII A metninin 399-406. satırlarına göre, Heruka'nın Anne ve Baba formu

BT VII A metninin 460-461. satırları arasında, (3) numaralı metinde, Heruka'nın Anne ve Baba formunda yab yum duruşu ile çeşitli Buda ve Bodisattvalarca çevrelendiği aşağıdaki temsil içerisinde görülmektedir:

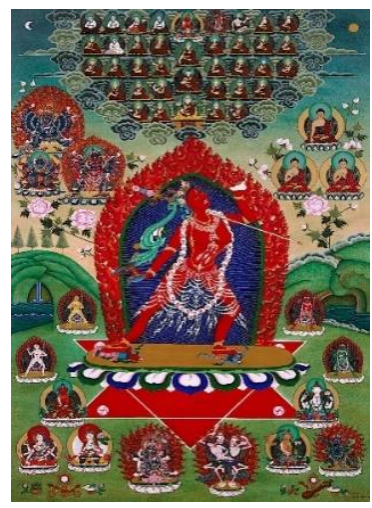

Resim VII: Buda ve Bodisattvalarca Çevrelenen Heruka'nın Anne ve Baba formu

Heruka dışında, Tibet Budizmi'ne dayalı Budist Uygur metinlerinde yab yum pozunu oluşturan ifadeler, BT VII H metninin 013-017. satırları arasında, (4) numaralı metinde görülmektedir. Bu metinde, tasvir edilen ilah, yeşil renkli, tek yüzlü ve iki kollu olarak sağ elinde kılıç ve sol elinde ghaṇtā denilan çan ya da zil tutmaktadır. Bu erkek ilahın kucakladığı, tanrıça yeşil renkte rüzgâr elementini

varlı̆ga devatā denilebileceği ilkesinden hareketle, tanrısallıkların çağrışımları, yalnızca göksel âlemlerin yüksek tanrılarını (devaloka) gerçek anlamda değil, aynı zamanda dinî düzeyde de kapsayacak şekilde genişletildi; evcil hayvanlar; ateş ve rüzgâr gibi güçlü dünyevi kuvvetler; nāgalar, gandharvalar ve yaksalar gibi daha küçük tanrılar; yerel hayaletler ve ruhlar şeklinde kapsamı genişletilen devatā kavramı, Budizm'in yeni bölgelere taşınması ile çeşitli yerel tanrıların Budist panteona dâhil edilmesini sağlamıştır (Buswell \& Lopez, 2014: 235). 
yöneten bir varlıktır. Burada bahsi geçen ilah, Amoghasiddhi ${ }^{10}$ ve onun Śaktisi ${ }^{11}$ Samaya-Tärā'dır. ${ }^{12}$ Uygurca metinde anlatılan tasviri şu şekilde görselleştirebiliriz. Resim VIII'de, her ne kadar Amoghasiddi'nin elinde belirli nesne sembolleri yer almasa da, onun kadın partneri ile cinsel kucaklaşmasını net bir şekilde görürüz:

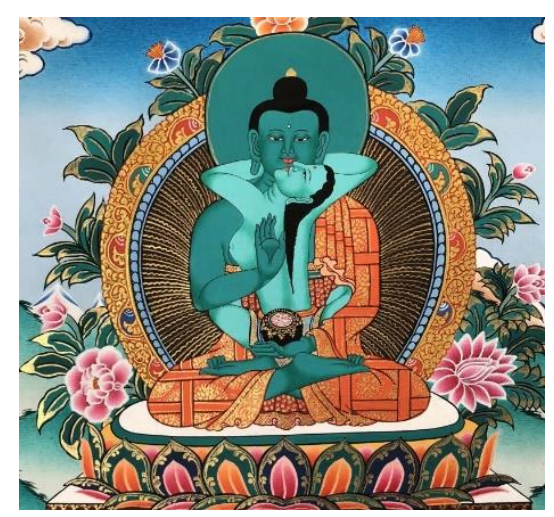

Resim VIII: Amoghasiddi Śaktisiyle yab yum pozunda

BT XXXVI D metninin 001-010. satırlarında, (5) numaralı metinde kadın ilahın erkek ilahı kucakladığı görülmektedir. Burada kadın olarak Māmaki ${ }^{13}$ ve

10 Pañcatathāgata'lardan biri asıl anlamı 'Başarıları Boşuna Olmayan' olan Karmakula ailesinin lideri, Amoghasiddhi'dir. Genellikle bir buda kılığında, yeşil renkte ve sağ eli Dhyānamudrä'da veya kalkık avucunda bir viśvavajra ile Dhyānāsana'da otururken tasvir edilir; sol eli Abhayamudrä'da göğsünde tutulur. Pañcatathāgata'nın Doğu Asya temsillerinde Amoghasiddhi genellikle Śākyamuni Buddha ile yer değiştirir (Buswell \& Lopez, 2014: 36).

11 Sanskritçe Śakti kelimesi 'güç' anlamına gelse de üç dişli bir mızrağa atıfta bulunur. Birçok eski tanrının sembollerinde śakti, güçlü bir alet ve silah olarak tasvir edilmiştir. Śakti, Hint ve Tantrik kültürlerde, ilahi vasfa sahip dişi form olarak tanrıça ve eş olarak görülür. Ḍākinīler, tanrıçalar veya Budizm'deki tanrıların kadın eşleri bilgelik sembolizmine sahip olup bu kadın tanrılara Śakti adı da verilir (Tibetan Buddhist Encyclopedia, Shakti maddesi).

12 Yeşil Tārā, Tibetliler tarafından orijinal Tārā olarak kabul edilir. Aslında, tanrıçanın Tibetçe adı, 'orijinal Tārā' anlamına gelen do-ngon'dur, ancak ngon, Lamalar tarafından 'yeşil' (veya mavi) anlamına gelen sngo ile karıştırılmıştır. Sağ ayağı bir lotus tahtında, ayağı küçük bir lotus tarafından desteklenmiş, sapı lotus tahtına tutturulmuş olarak tasvir edilmiştir. Beyaz Tārä’nınkinden biraz daha hareketli olan pozunda narin ve ağırbaşlıdır. Bir Bodisattva gibi giyinir ve on üç süs eşyası ve genellikle beş kurşunlu taç giymektedir. Saçları gür ve dalgalıdır. Tibet tapınak flamalarında, Yeşil Tārāa, on tanesi beyaz, beşi kırmızı, beşi sarı ve merkezde Yeşil olan yirmi bir Tārā grubunu temsil eden bir çift gökkuşağı ile çevrili olarak tasvir edilebilir. Resmin sağ köşesinde yedi gözün Beyaz Tāră’sı, solunda ise tanrıça Ușnịșavijayā vardır. Sağ alt köşede Dharmapāla, Begt'se, sol alt köşede ise dik saçlarında üç at başı olan tanrı Hayagrivi vardır. Bu tanrıların ikisi de kırmızı renktedir (Getty, 1928: 123, 124).

13 Mücevher Ailesi içerisine mensup olan Māmakī, bu grup dışında Vajra (Akșobhya) ailesine de mensuptur (Bhattacharyya, 1958: 52). Ratnasambhava bir eş ile tasvir edildiğinde, bu ya Locanā ya da 


\section{J(ब)}

erkek olarak Ratnasambhava ${ }^{14}$ arasındaki cinsel kucaklaşma sembolizi anlatılmaktadır. Toprak elementi saflığında sarı renkte görülen Ratnasambhava'nın partneri Māmakī, sağ elinde bir ritüel bıçağı ve sol elinde kapala denilen kafatası tutarak Buda Babasını yani Ratnasambhava'yı kucaklamaktadır. Māmakì ve Ratnasambhava'nın etrafı, altmış dört tanrı kızları çevrelenmektedir. Bu anlatıma yakın bir temsili şöyle gösterebiliriz:

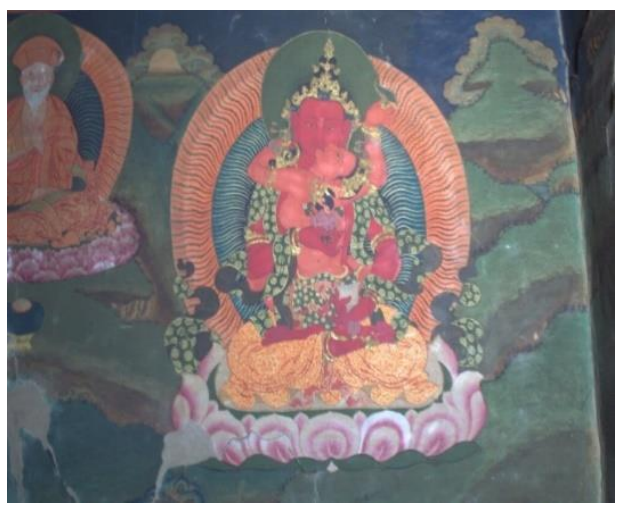

Resim IX: Ratnasambhava ve Māmakī yab yum formunda

Son olarak BT XXXVI D metninin 011-019. satırları arasında, (6) numaralı metinde, Amoghasiddhi Buda'nın yab yum formunda cinsel kucaklaşma yaşayacağ Samaya-Tārä'dır. Amoghasiddhi, bu tasvirde yeşil renkte, sağ elinde ritüel bıçă̆ı, sol elinde ghanțā denilen çan ya da zil tutmaktadır. Bu anlatım, (4) numaralı metinle uyuşmaktadır. Yeşil renkli rüzgar elementini yöneten yeşil Tārā yani Samaya-Tārā, Amoghasiddhi ile aynı renkte sağ elinde ritüel bıçağı ve sol elinde kapala denilen bir kafatası tutmaktadır. Amoghasiddhi, elindeki nesnelerle Buda Annesi'ni kucaklar durumdadır. Bu anlatımı, şöyle görselleştirebiliriz:

Māmakỉ'dir. Beş tathāgata'dan en az bilineni olan Ratnasambhava, nadiren tek başına tasvir edilir ve kült hâline gelmemiş gibi görünmektedir (Buswell \& Lopez, 2014: 704). Ayrıca, Akṣobhya'nın Buddhakṣetra veya Abhirati'nin Saf Ülkesi Doğu'da bulunur, bazen mandalalarda yerini aynı yönde bulunan Bhaișajyaguru ile değiștirir. Akșobhya'nın en yaygın mudrā’sı Bhūmisparśamudrā'dır ve genellikle bir vajra'ya sahiptir (Buswell \& Lopez, 2014: 704).

14 Ratnasambhava, Vajrayana Budizmi'nde Beş Meditasyon Budası'ndan biridir. Evrenin duyularla ilgili dalını temsil eden Ādibuddha'nın bir ürünü olarak sarı mantra sembolü Tram hecesinden gelir ve Güney cennetinde yaşamaktadır. Śaktisi Māmakìdir ve kendisine iki aslan veya at eşlik eder. Sarı renkte koruyucu tanrı olarak kabul edilir, elinde çan ve mücevher bulunur. Yayılımları arasında Aparājita, Jambhala, Mahaprattisara, Prasannatara, Ratnapani, Vajratara, Vajrayogini ve Vasudhara yer alır (Jordan, 2004: 263, 264). 


\section{Ј(-()}

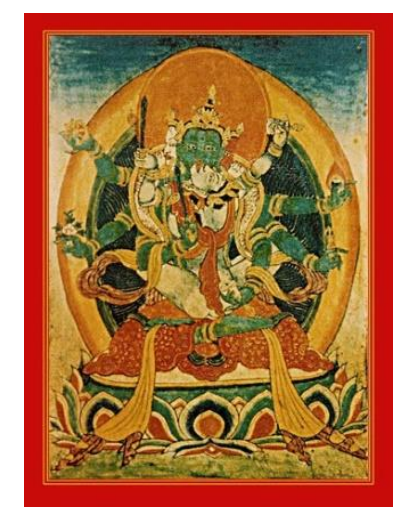

Resim X: Amoghasiddhi ve Samaya-Tārā yab yum pozunda

Ayrıca, Heruka'nın anne ve baba formu özellinde genellikle yab yum sembolizmi içerisinde görülen terimlerden biri de, sağ elde vajra ya da sol elde ghanțā denilen çan ya da zilin tutulduğu pozdur. Bu poz, Sanksritçede vajrahūmkāra karşıllğına sahiptir. Tibetçede $r$ do rje hūm mdzad ve Çincede 䌸曰罗 吽金钢印 縳曰羅吽金鋼印 zhuànyue luóhōngjingāng yìn olarak görülen bu terim, Tantrik ikonografilerde bazen cinsel kucaklaşma olarak adlandırılan, tanrının ellerinin (genellikle bir vajra ve bir çan tutan) göğüste çaprazlandığı bir pozisyon için kullanılan terimdir. Eğer tanrı dişi eşle cinsel kucaklaşıyorsa, eller eşinin arkasında çaprazlanır ve onu kucaklar. Eğer bir eş yoksa da eller tanrının göğsünün üzerinde çaprazlanır (Buswell \& Lopez, 2014: 954):

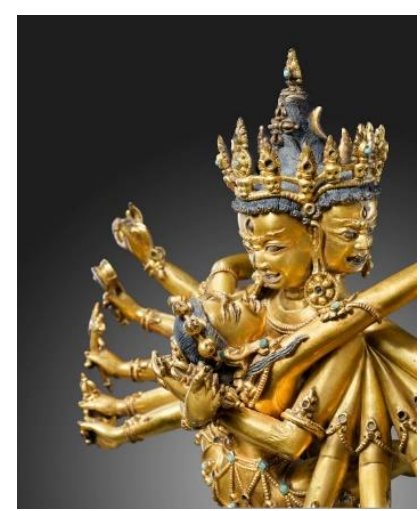

Resim XI: Yab yum pozunda vajrahūm kāra duruşu

Bazen elmas mudrā olarak adlandırılan bu hareket, iki eli yumruk hâline getirerek (başparmaklar içerideyken) ve bilekleri göğsün önünde çaprazlayarak yapılır. Çeşitli türleri olmakla birlikte, genellikle bileğin avuç içi yüzü, vücuttan uzağa bakar ve sağ kol göğse sol koldan daha yakındır (Bazen avuç içleri içeri bakar ve sol kol göğse daha yakındır). Bazen sağ el bir vajra (erkek sembolizmi) ve sol el bir ghanțāa veya çan (kadın) tutar, ancak bu nesneler hayal gücüne 


\section{0}

dayalıdır, değişebilir. İkisi, vajra ve ghanțā’nın birlikte kullanımı, yol ve amaç anlamına gelir, burada birleşme söz konusudur. Bu poz, yanılsamayı yenme olarak elmasın dayanıklılığını temsil eder (Tibetan Buddhist Encyclopedia, Vajrahūmkāra Mudrā maddesi).

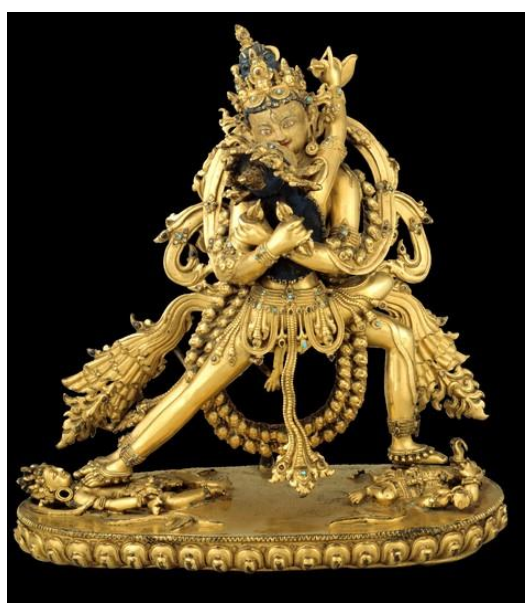

Resim XII: Yab yum pozunda vajrahūmkāra duruşu

Resim VII ve VIII'de gösterilen temsillerin Budist Uygur metinlerindeki görünümüne bakıldığında, BT VII A Metninin 399-406. satırları arasında, (2) numaralı metinde, Heruka'nın sağ elinde vajra, sol elinde çan tuttuğu görülmektedir, bu da yab yum sembolizmi özelinde vajrahūmkāra duruşunu göstermektedir. BT VII H metninin 013-017. satırlarında, (4) numaralı metinde, sağ elde vajra olmadan sol elde kılıç saplı çan ile ilah ve ilahenin yab yum pozunda cinsel birliktelik yaşadığı görülmektedir. Burada vajra yerine, kılıç sembolünün kullanılması, Tibet sembolizmi açısından en azından vajra kadar, önemli bir sembolün varlığını da bizlere göstermektedir. Tibet Budizmi'nde kılıç (Sanskritçe khadga, Çince 堨伽, 謁誐, Tibetçe ral gri) ${ }^{15}$, Cakravartin'in ${ }^{16}$ değerli

15 Terimin karşılıkları için Beer, 1999: 163, Porció, 2000: 109 ve SH, 1937: 426’tan yararlanılmıştır.

16 Genellikle 'evrensel hükümdar veya imparator' olarak tercüme edilen Cakravartin terimi, 'tekerlek çeviren' veya 'her yerde engelsiz dönen bir çark' anlamına gelir. Cakra veya tekerlek ifadelerinin çeşitli yorumları vardır. Güneşin ateşli çarkına veya güneş tanrısının haftanın yedi gününü temsil eden yedi atın çektiği gökyüzünde giden iki tekerlekli (gök ve yer) arabasına da atıfta bulunabilir. Cakra, Vișnu'nun bir amblemi olarak, ilahi varlıkların avuçlarında ve tabanlarında uğurlu bir işaret olarak görünen disktir. Bir arazi ölçüsü birimi olarak cakra, bir arazinin kıyıdan kıyıya tüm yüzey alanını ifade eder. Bu, ufkun kenarına dokunan cakranın veya merkezi bir yerden bakıldığında bir disk olarak görülen araziyi çevreleyen noktaları ifade eder. Çarkın dönmesi hem seküler hem de dinî otoriteyi sembolize eder. Bu terim, değişimi, hareketi, yayılmayı, fetih ve yeni bir etik ve ahlakî düzenin oluşumunu ifade eder. Ayrıca, cakra terimi ile Budist öğretilerinin kurtuluşu ve iletilmesi, dharma çarkını çevirmek olarak bilinir. Cakravartin kavramı muhtemelen, kökenleri eski Hindistan'ın Vedik ve 


\section{Ј(৫)}

aksesuarı olarak genellikle dik olarak gösterilir. Kılıç, sembolik olarak karanlığı hem fiziksel hem de ruhsal olarak aydınlatır ve Māraları ${ }^{17}$ ve şeytan ordularını korkutur. Özellikle, Cakravartin'in kılıc1, muazzam bir güce sahip bir silahtır. Bu kılıç, kan dökmeden düşmanları alt eder, cehaletin derinliklerine nüfuz eder (Beer, 1999: 163, 164). BT XXXVI D metninin 001-010. satırları arasında, (5) numaralı metinde sağ elde Sanskritçede nirvāsa (Kara \& Zieme, 1976: 50) olarak bilinen Tantrik ritüel bıçağının (Uygurca navaskart) ve sol elde kafatası olarak bilinen kapala'nın olduğu görülmektedir. Burada, her ne kadar, vajra ve ghanțāa gibi erkek ve kadın birleşmesini sembolize eden nesneler kullanılmasa da, önceki pasajda söylenildiği üzere, yab yum formunda kişinin hayal gücüne göre elde tutulan nesnelerin değiştiği görülmektedir. Son olarak yine vajrahūmkāra duruşunu yansıtan anlatım, BT XXXVI D metninin 011-019. satırları arasında, (6) numaralı metinde görülmektedir. İlgili bölümde, yab yum formunda sağ elde kılıcın sol elde de kılıç saplı bir ghanțā’nın yani çanın olduğu görülmektedir. Bu durum, (5) numaralı metinde olduğu gibi, kişinin yab yum pozunda hayal gücüne bağlı olarak tutulan nesneler arasında değişmelerin olabileceğini yansıtmaktadır.

\section{Sonuç}

Buda öğretisi ve Buda topluluğunun savunduğu aydınlanma fikrine tezat oluşturan ve çoğu durumda manastır üyeleri tarafından ihlal edildiğinde, dharma topluluğunun düzenini ve öğretiyi olumsuz yönde etkileyeceği düşünüldüğü için Budistlerce hoş karşılanmayan cinsellik kavramı, Tibet Budizmi'ne değin Klasik ve Mahāyāna Budizmi geleneklerinde dharma içerisine sokulmayan ve manastır üyelerine tamamen yasaklanan bir eylemdir. Cinsellik kavramına olan bakışı ve

Puranik destanlarında bulunan ‘büyük adam' fikrinden doğmuştur. Böyle bir varlık bir dünya lideri olarak herhangi bir zamanda dünyada sadece bir tane olan Buda gibi olabilir (Beer, 1999: 160, 161).

17 Māra, Budizm'de kötülüğün kişileştirilmesi ve genellikle Budist şeytan olarak anılır; aslında o, varlıkların yeniden doğuştan kurtulmasını ve böylece ölümün üstesinden gelmesini engellemeye kendini adamış, duyusal âlemin (kāmadhātu) güçlü bir tanrısıdır. Buda'nın biyografilerinde Māra, Buda'nın düşmanı olarak görülür. Bodisattva Siddhārtha, saṃsāra'dan kurtuluşa ulaşana kadar yükselmemeye yemin ederek Bodhi ağacının altına oturduğunda, onu arayışından caydırmaya çalışan Māra ona yaklaştı. O reddedince, Māra kızlarını onu yok etmeleri için gönderdi. Kızlarını Ratī (hoşnutluk), Aratī (hoşnutsuzluk) ve Trsnä’yı (özlem) onu baştan çıkarmaya gönderdiğinde, Bodisattva hareketsiz kaldı, bazı anlatılarda onları cadılara dönüştürdü ve sonra onlar tövbe ettikten sonra güzelliklerini geri verdi (Buswell \& Lopez, 2014: 530). 


\section{ग(๑)}

yüklenen anlamı, çeşitli değerlendirmeler ışığında kadına yakıştırılan "Māra gibi şeytan, baştan çıkarıcı, ayartıcı vb." ifadelerle de görmekteyiz.

Tibet Budizmi'ne dayalı dinî gelenekte, erkek ilah ile kadın ilah arasındaki cinsel birlikteliği yansitan Tibetçe yab yum terimi, daha çok meditasyon durumunda düşünülen ya da birebir canlandırılan cinsel bir sembolizm olarak kişinin kendi bedeninde yaşadığı mistik deneyimi anlatan bir terimdir. Yab yum figürü, Budist Uygurlarda kendisini Tibet Budizmi etkisi ile göstermiştir. Tantrik Türk Budizmi'ne ait metinlerde ög kay, ög t(e)gri kızı, kuç- ve kuçmak ifadeleriyle ikonografik olarak anlatılan yab yum, Tantrik Türk Budizmi'ne ait metinlerde, Heruka, Amoghasiddhi-Samaya-Tārā 'yeşil Tārā’ ve Ratnasambhava-Māmakī özelinde görülmüsşür. Özellikle Heruka'ya ait yab yum formunda, mandala merkezli anlatımda Beş Meditasyon Budası ve onlarla birlikte altıncı Buda Vajrasattva, cakra sistemleri ve Devatā gibi kavramlar element ve yönlerle gösterilerek Heruka'nın yab yum formu hakkında fizyolojik bilgiler de verilmiştir. Ayrıca, Tantrik Türk Budizmi'ne ait metinlerde bu kişiliklere dair, yab yum formunda verilen bilgilerin, çalışma içerisinde gösterilen resimlerle uyumlu olduğu ve Tantrik Türk Budizmi içerisinde anlatım bulan yab yum formunun Budist Uygurlarda aydınlanma hedefini gerçekleştirecek Cinsel Kucaklaşma teması içerisinde, aynı sembolik anlatımların varlığı da söz konusudur. Bu durum, Budizm içerisinde bir yenilik hareketi olarak beliren Tantracı geleneğin Budist Uygurlarda karşılıklar bulduğunu ve Uygurların bu yeni mezhep etrafında dinî bir edebiyat ve dinî bir yaşam tarzı oluşturduklarını bizlere göstermektedir.

\section{Kaynakça}

Beer, R. (1999). The Encyclopedia of Tibetan Symbols and Motifs. Boston: Shambhala Publications.

Bhattacharyya, B. (1958). The Indian Buddhist Iconography, Mainly Based on The Sādhanamālā and Cognate Tantric Texts of Rituals. Calcutta: Mukhopadhyay.

Blofeld, J. (1992). The Tantric Mysticism of Tibet: A Practical Guide to the Theory, Purpose, and Techniques of Tantric Meditation. USA: Penguin Books.

Buswell, R. E. \& Lopez, D. E. (2014). The Princeton Dictionary of Buddhism. Princeton: Princeton University Press.

Buswell, R. E. (2004). Encyclopedia of Buddhism I-II. Detroit: Thomsen Gale. 
Donaldson, T. E. (2001). Iconograpy of The Buddhist Sculpture of Orissa I (Text). New Delhi: Indira Gandhi National Centre For The Arts Abhinav Publications.

Gendun Chopel (2018). The Passion Book: a Tibetan Guide to Love \& Sex. Trans. Donald S. Lopez Jr. \& Thupten, J. Chicago: The University of Chicago Press.

Geshe Kelsang Gyatso (1997). Essence of Vajrayana: The Highest Yoga Tantra Practice of Heruka Body Mandala. New York: Tharpa Publications.

Getty, A. (1928). The Gods of Northern Buddhism. Their History, Iconography and Progressive Evolution Through the Northern Buddhist Countries. Oxford: Clarendon Press.

Gordon-White, D. (2000). Tantra in Practice. Princeton: Princeton University Press.

Gray, D. (2007). The Cakrasamvara Tantra (The Discourse of Sri Heruka): Śrīherukābhidhāna: A Study and Annotated Translation (Treasury of the Buddhist Sciences). USA: Wisdom Publications.

Heroldová, H. (2016). "Father and Mother": Tantric Couples in the Collection of the Náprstek Museum and the History of the Collection Description. Annals of the Náprstek Museum, 37(1), 71-86.

Jones, K. H. (2003). The New Social Face of Buddhism: A Call to Action. USA: Wisdom Publications.

Jordan, M. (2004). Dictionary of Gods and Goddesses. London: Routledge \& Kegan Paul.

Kara, G. \& Zieme, P. (1976). Fragmente tantrischer Werke in uigurischer Übersetzung. Berliner Turfantexte VII. Berlin: Akademie Verlag. ( $\rightarrow$ BT VII)

Keown, D. (2003). Dictionary of Buddhism. Oxford: Oxford University Press.

Lee, K. S. (2005). East and West: Fusion of Horizons. USA: Homa \& Sekey Books.

Lessing, F. D. (2017). Moğolca-Türkçe Sözlük. Çev. Karaağaç, G. Ankara: Türk Dil Kurumu Yayınları.

Müller, F. W. K (1928). Ein uigurisch-lamaistisches Zauberritual aus den Turfanfunden. Sitzungsberichte, der Preußischen Akademie der Wissenschaften, Phil.hist. Klasse (pp. 381-386). Berlin: Walter de Gruyter.

Neville, R. C. (1987). New metaphysics for eternal experience. Journal of Chinese Philosophy, 14, 357-370.

Odin, S. (1982). Process Metaphysics and Hua-Yen Buddhism: A Critical Study of Cumulative Penetration Vs. Interpenetration. USA: Suny Press. 
Peng, J. (2013). An Exploration of Tibetan Tantric Buddhism and its Art: A Potential Resource for Contemporary Spiritual and Art Practice. University College London, Slade School of Fine Art (Unpublished PhD Thesis).

Peng, J. et al. (2020). Yab-Yum Images: The Most Controversial form in Tibetan Tantric Buddhism and its Art. International Journal of Management and Applied Science (IJMAS), 6(1), 52-56.

Porció, T. (2003). On the tecnique of translating Buddhist texts into Uygur. In Sven, B. \& Wilkens, J. (Eds.). Indien und Zentralasien-Sprach- und Kulturkontakt (pp. 85-94). Wiesbaden: Harrassowitz Verlag.

Porció, T. (2000). The One with the White Parasol, Four Sitātapatrā Texts in the Derge Kanjur and a Dunhuang Text (Pelliot Tibétain No. 45) with an Annotated English Translation of the Longest Canonical Version. Faculty of Arts of the University of Vienna. (Unpublished PhD Thesis).

Powers, J. (2009). Introduction to Tibetan Buddhism. New York: Snow Lion.

Simmer-Brown, J. (2002). Dakini's Warm Breath: The Feminine Principle in Tibetan Buddhism. Boston: Shambhala.

Soothill, W. E. \& Hodous, L. (1937). A Dictionary of Chinese Buddhist Terms with Sanskrit and English Equivalents and Sanskrit-Pali Index. London: Kegan Paul.

Sørensen, H. H. (2011). Central Divinities in the Esoteric Buddhist Pantheon in China. In Orzech, C. D. et al. (Eds.), Esoteric Buddhism and the Tantras in East Asia (pp. 90132). Leiden-Boston: Brill.

Thurman, R. A. F. (2010). Brilliant Illumination of the Lamp of the Five Stages (Rim lnga rab tu gsa/ ba'i sgron me) Practical Instruction in the King of Tantras, The Glorious Esoteric Community by Tsang Khapa Losang Drakpa. New York: The American Institute of Buddhist Studies Columbia University Center for Buddhist Studies.

Tucci, G. (1980). The Religions of Tibet. Trans. Samuel, G. London: Routledge \& Kegan Paul.

Uçar, E. (2013). Uygurca Altun Yaruk Sudur IX. Tegzinç [金光明最勝王經卷第九] Diplomatik Neşir Usûlüyle Yayını, Tercüme, Açılamalar ve Dizin. İzmir: Dinozor Kitabevi Yayınları.

Wilkens, J. (2021). Handwörterbuch des Altuigurischen, Altuigurisch-DeutschTürkisch. Göttingen: Universitätsverlag Göttingen. 


\section{J(O)}

Yakup, A. (2016). Altuigurische Aparimitāyus-Literatur und kleinere tantrische Texte. Berliner Turfantexte XXXVI. Turnhout (Belgium): Brepols Publishers. ( $\rightarrow$ BT XXXVI)

\section{Elektronik Kaynaklar}

\section{Açıklamalarda Kullanılan Elektronik Kaynaklar}

Chinese English Pinyin Dictionary (www.chinese.yabla.com)

Encyclopedia Britannica (www.britannica.com)

Hopkins, J. Tibetan-Sanskrit-English Dictionary (www.glossaries.dila.edu.tw).

Tibetan Buddhist Encyclopedia (www.tibetanbuddhistencyclopedia.com).

Türkçe Sözlük (www.sozluk.gov.tr).

\section{Resimlerde Kullanilan Elektronik Kaynaklar}

\section{Resim I}

www.britannica.com/topic/yab-yum.

\section{Resim II}

www.britannica.com/topic/yab-yum

\section{Resim III}

www.buddhamuseum.com/samanthabadra-yabyum_28.html

\section{Resim IV}

http://files7.webydo.com/90/9020472/UploadedFiles/206a0801-6633-4374-b4afe8e422c602db.pdf

\section{Resim V}

Geshe Kelsang Gyatso, 1997: 238.

\section{Resim VI}

https://buddhaweekly.com/whats-consort-union-tantric-buddhism-no-notsexual-fantasies-psychology-yab-yum-consorts-union-wisdom-compassion/

\section{Resim VII}

https://buddhaweekly.com/wp-content/uploads/Buddha-Weekly-beautifulvajrayogini-mandala-and-lineage-Buddhism.jpg 


\section{J(৫)}

Resim VIII

https://blog.mesindesgalantes.com/wp-

content/uploads/2017/09/Amoghasiddhi-tara.jpg

\section{Resim IX}

https://images.mandala.library.virginia.edu/image/painting-buddharatnasambhava-and-consort-mamaki

\section{Resim X}

http://tibetanbuddhistencyclopedia.com/en/?title=File:Amoghasiddhi_and_Sa mayatara.jpg

\section{Resim XI}

https://images2.bonhams.com/image?src=Images/live/2015-01/12/9098143-45.jpg\&width $=960$

\section{Resim XII}

https://har-assets.s3.amazonaws.com/item-images-resized/535px/6/5/4/ 65438.jpg 